\title{
Categorical Analysis in Antitrust Jurisprudence
}

\author{
Mark A. Lemley
}

and

Christopher R. Leslie

John M. Olin Program in Law and Economics

Stanford Law School

Working Paper No. 348

November 2007

This paper can be downloaded without charge from the

Social Science Research Network 


\title{
Categorical Analysis in Antitrust Jurisprudence ${ }^{1}$
}

\author{
Mark A. Lemley ${ }^{2}$ \& Christopher R. Leslie ${ }^{3}$
}

I. The Role of Categorization in Antitrust Analysis

A. Modes of Antitrust Analysis

1. The Per Se Rule

2. Rule of Reason Analysis

3. "Quick Look" and the Abbreviated Rule of Reason

4. Categories or Continuum?

B. Characterizing restraints.

1. Horizontal versus Vertical

2. Naked versus Ancillary

3. Voluntary Versus Coerced Restraints

4. Unilateral versus Concerted Restraints

5. Obsolete Categories

a. Price versus Nonprice

b. Maximum versus Minimum Pricing

II. Problems with Reliance on Categorical Analysis.

A. Shifting Categories

1. Price-Fixing

2. Group Boycotts

3. Information Exchanges

B. Categories Subject to Manipulation.

1. Horizontal versus Vertical
a. Cooperatives
b. Dual Distribution
c. Group Boycotts
d. Summary

2. Voluntary versus Coerced.

3. Unilateral v. Concerted Conduct

a. Is it a Joint Venture? Collaborations Among Competitors

b. Dealer Terminations

c. Conditional Refusals to Deal

d. Who Is a Single Actor?

C. Categories That Lie: Tying

${ }^{1}$ (c) 2007 Mark A. Lemley \& Christopher R. Leslie.

William H. Neukom Professor, Stanford Law School; of counsel, Keker \& Van Nest LLP.

3 Visiting Professor of Law, NYU School of Law (Spring 2008); Professor, Chicago-Kent College of Law.

Yes, we are aware of the irony of writing a taxonomy of the problems with taxonomies.

We thank Michael Carrier, Dan Crane, Rose Hagen, Herb Hovenkamp, and Tony Reese for insightful comments on earlier drafts of this paper. Remaining mistakes and omissions are our responsibility. 
D. Categories That Are Nonsensical: Sales versus Licenses

E. Different Category Labels For the Same Conduct

1. Predatory Bundling

2. Refusals to License IP Rights

3. Tying

III. A More Nuanced Approach to Antitrust Analysis

A. The Value of Categories

B. Currently, the Costs of Categories Outweigh Their Benefits.

C. On the Correct Use of Categories in Antitrust

1. The Goals of Antitrust

2. The Importance of Empiricism

3. Greater Reliance on Antitrust Injury

4. Direct Evidence of Anticompetitive Effects

\section{Conclusion}

In the Scientific Revolution during the Age of Enlightenment, scientists and natural philosophers sought to understand the world by categorizing it. Specimens of rocks, plant life, and animal life were collected and sorted into groups based on perceived similarities and differences. For example, animals were cataloged as vertebrates or invertebrates based on whether they had backbones. Ultimately, each living organism was categorized into a kingdom, phylum, class, order, family, genus, and, finally, species. This process of categorizing the natural world represented a milestone in man's intellectual development. However, the limitations of this period of scientific progress became apparent as over time it became clear that some categories made little sense, some individual classification decisions were inaccurate, and some species - notably the duck-billed platypus - defied classification altogether. ${ }^{4}$ As a result, the classification schemes had to adapt both as new species were discovered and as old categories proved to be ill-conceived. ${ }^{5}$

\footnotetext{
${ }^{4}$ Harriet Ritvo, The Platypus and the Mermaid AND Other Figments of The Classifying IMAGINATION 3- 12 (1997).

${ }^{5}$ Id. at 11-17; id at 26 ("Whether or not they appreciated Linneaus's work, it became increasingly clear to eighteenth-century British naturalists - as , indeed, it had been clear to Linneaus himself - that his system
} 
The classification schemes pursued during the Enlightenment and the lessons learned during these early attempts at categorization are surprisingly similar to the evolution of the common law of antitrust. But there is an important difference: in law, categories have real consequences. Calling a platypus as a mammal doesn't change the fact that it lays eggs. ${ }^{6}$ But calling a particular competitive practice by one name or another often has dramatic consequences for whether or not the law permits it. In this article, we suggest that the Enlightenment enthusiasm for taxonomy has run amok in antitrust law, with pernicious consequences.

$* * * * * * * * * * * * * * * * *$

Legal doctrines vary in the extent to which they apply either detailed, categorical rules or broad, open-ended standards that allow for case-specific adjudication. We can put legal rules on a spectrum from rules to standards. Think of the tax code as the paradigm example of specified rules, and of the common law development of doctrines such as negligence as the paradigm example of case-specific standards. Other laws fall somewhere in between: the securities laws and the patent laws mix specific rules governing some aspects of doctrine with broader standards such as Rule 10b5 in securities fraud or the doctrine of obviousness in patent law.

was artificial, in the sense that it tended to group animals on the basis of single characteristics, such as 'dentition or the form of feet,' often selected largely for classificatory convenience.”).

${ }^{6}$ At least one major scientist of that early era did, in fact, assert that platypuses could not lay eggs, in order to defend his own taxonomy of Australian mammals. Id. at 14 ("In order to defend his position, Owen had to deny that the platypus laid eggs, a denial that implicitly identified another way in which the taxonomy of Australian mammals had become a representative arena for contests between rival authorities."). Many other observers confidentally declared that the egg-laying platypus was a hoax. Id. at 15 ("Several years later, while describing a stuffed platypus on display at the Australian pavilion of the Colonial and Indian Exhibition, the Illustrated London News smugly reported that 'fables were formerly told of this queer creature, as that it laid eggs."'). 
Antitrust law is generally thought of as inhabiting the standards end of this spectrum. ${ }^{7}$ The basic enabling statutes offer only vague proscriptions against "monopolization" or "contracts, combinations, or conspiracies in restraint of trade." Antitrust's rule of reason in particular gives courts the power and responsibility to weigh the costs and benefits of a particular defendant's conduct. And numerous courts and scholars identify (and often lament) the uncertain, open-ended nature of the basic rule of reason inquiry. ${ }^{9}$

In fact, however, despite the generality of the enabling statutes antitrust law is rife with categorical distinctions. In Part I, we explore not only the well-known distinction between conduct that is per se illegal and conduct judged under the rule of reason, but also a number of categorical distinctions the courts draw, either to help delineate the scope of the per se rule or to create distinctions within the scope of the rule of reason itself. By and large these rules don't come from the antitrust statutes. They are created by courts, who are in effect converting case-specific standards en masse into categorical rules.

In Part II, we identify a number of problems with these distinctions. One problem is administrative: courts spend a great deal of time trying to parse conduct in order to put it on one side or another of the lines they have created. Indeed, in many cases courts spend more time on categorization than they do on actual economic analysis of the case itself. Second, judicial antitrust categories are subject to manipulation. Parties go to great lengths to fit into a box that will give them more favorable treatment, sometimes by legal

7 See, e.g., Daniel A. Crane, Rules Versus Standards in Antitrust Adjudication, 64 Wash. \& Lee L. Rev. 49 (2007).

815 U.S.C. $\S \S 1,2$.

9 See, e.g., Crane, supra note _; Frank H. Easterbrook, The Limits of Antitrust, 63 Tex. L. Rev. 1 (1984). 
argument, sometimes by restructuring a transaction, and sometimes by concealing or misrepresenting the facts of that transaction. Third, a number of the categories the courts have created make no sense, whether because they have lost their meaning over time, because their boundaries have eroded, because they actually tell us very little of relevance to the competitive effects of the transaction, or because they are simply dumb. The net result is a mess. Categories have become conclusions, displacing the fact-specific economic analysis in which antitrust law is supposed to be engaging.

In Part III, we argue that there is a better way. We evaluate the costs and benefits of the judicial creation of categories, and contend that the complex of antitrust boxes the courts have created today does more harm than good. We don't mean to suggest there is no value to categories, and that everything must be thrown into a pure cost-benefit analysis. Some rules (the per se rule against price fixing, for instance) make sense. Rather, the important thing is to make sure that the categories we use have empirical support, and that they are communicating valuable information to courts about the competitive effects of a general practice. We think the courts have gone too far in the creation of rules in a variety of cases. Finally, we suggest that courts make more use than they do of certain tools - the doctrine of direct economic effect and empirical evidence as powerful filters for distinguishing good from bad antitrust claims.

\section{The Role of Categorization in Antitrust Analysis.}

Section one of the Sherman Act is notoriously vague. The statute provides, in relevant part, that "[e]very contract ... in restraint of trade ... is declared to be illegal."10 Read literally, the sweep of the language outlaws contracting entirely, as every contract

1015 U.S.C. $\S 1$. 
restrains trade in some way. ${ }^{11}$ Resort to legislative history does little to inform our interpretation, as it demonstrates only that Congress intended the courts to translate section one's overreaching wording into a workable legal doctrine. Naturally unwilling to interpret section one as broadly as written, the Supreme Court reasoned that section one condemns only unreasonable restraints of trade. ${ }^{12}$ The task for antitrust courts then became how to determine whether a particular agreement was, in fact, unreasonable.

Courts have approached this overarching reasonableness determination through a process of categorization. There are two primary forms of categorical analysis in antitrust jurisprudence. First, the Sherman Act itself distinguishes between unilateral and concerted conduct, treating the former under section 2 of the Sherman Act and the latter under section 1. Second, the Supreme Court categorized challenged restraints as being subject to under either per se illegality or analyzed under the 'rule of reason.' Beyond these two basic distinctions, courts characterize individual restraints along a series of categorical vectors, in large measure to determine which mode of analysis to apply. ${ }^{13}$

\section{A. Modes of Antitrust Analysis.}

\footnotetext{
${ }^{11}$ See Leegin Creative Leather Products, Inc. v. PSKS, Inc., 127 S.Ct. 2705 (2007) (“§ 1 could be interpreted to proscribe all contracts") (citations omitted).

${ }^{12}$ Standard Oil Co. of N.J. v. United States, 221 U.S. 1 (1911).

13 Dan Crane argues that antitrust is moving from rules towards standards. Crane, supra note While this is true in some respects, as the courts have cabined or eliminated per se rules, in many cases this weakening of per se rules has taken the form not of replacing per se rules with standards, but of building categories to divide per se from rule of reason analysis. We discuss several examples in the sections that follow.

Our examples are concentrated in section 1 of the Sherman Act, though we also venture into section 2. For an argument along similar lines confined to section 2 monopolization cases, see Einer Elhauge, Defining Better Monopolization Standards, 56 Stan. L. Rev. 253, 253 (2003) ("Monopolization doctrine currently uses vacuous standards and conclusory labels that provide no meaningful guidance about which conduct will be condemned as exclusionary.").
} 
Federal courts have developed three modes of analysis for determining whether a particular agreement unreasonably restrains trade.

\section{The Per Se Rule}

The per se rule provides the most direct mechanism for a plaintiff to establish that a challenged restraint of trade is unreasonable. The Supreme Court has explained that "there are certain agreements or practices which because of their pernicious effect on competition and lack of any redeeming virtue are conclusively presumed to be unreasonable and therefore illegal without elaborate inquiry as to the precise harm they have caused or the business excuse for their use."14 Such agreements are per se illegal. If a contract or conspiracy falls within the ambit of the per se rule, the plaintiff need not prove anticompetitive intent or effect. Nor will the defendant's purported noble motives save the agreement from condemnation. ${ }^{15}$ The per se rule "allows a court to presume that certain limited classes of conduct have an anticompetitive effect without engaging in the type of involved, market-specific analysis ordinarily necessary to reach such a conclusion."16

\footnotetext{
${ }^{14}$ Northern Pac. Ry. v. United States, 356 U.S. 1, 5 (1958); Nynex Corp. v. Discon, Inc., 525 U.S. 128,133 (1998) (some agreements are per se illegal because they "will so often prove so harmful to competition and so rarely prove justified that the antitrust laws do not require proof that an agreement of that kind is, in fact, anticompetitive in the particular circumstances"); see also Eastman Kodak Co. v. Image Technical Services, Inc., 504 U.S. 451, 486-87 (1992) (Scalia, J., dissenting) ("Per se rules of antitrust illegality are reserved for those situations where logic and experience show that the risk of injury to competition from the defendant's behavior is so pronounced that it is needless and wasteful to conduct the usual judicial inquiry into the balance between the behavior's procompetitive benefits and its anticompetitive costs.").

${ }^{15}$ Yarn Processing Patent Validity Litigation, 541 F.2d 1127, 1134 (5th Cir. 1977) (citing United States v. Topco Assoc., 405 U.S. 596 (1972); White Motor Co. v. United States, 372 U.S. 253 (1963))

${ }^{16}$ Pace Elecs., Inc. v. Canon Computer Sys., Inc., 213 F.3d 118, 123 (3d Cir. 2000).
} 
The per se rule represents a categorical approach for concluding that a challenged restraint is unreasonable. Since the inception of the per se rule, the Supreme Court has consistently acknowledged that the per se rule applies to "[c]ertain categories of agreements ${ }^{17}$ and "permits categorical judgments." ${ }^{\prime 18}$ In its most recent section one opinion, 2007's Leegin decision, the Court notes that the "per se rule [] treat[s] categories of restraints as necessarily illegal."19 Indeed, since the point of the per se rule is to avoid a detailed, case-by-case inquiry into the benefits and harms of particular conduct, it would make little sense to have a per se rule that wasn't categorical. A practice should not be considered illegal per se if courts have to evaluate it on the merits to decide whether it qualifies for the per se rule in the first place.

\section{Rule of Reason Analysis}

Generally speaking, agreements that do not fall in a per se category are evaluated under the rule of reason. The vast majority of trade restraint categories receive rule of

\footnotetext{
${ }^{17}$ Business Electronics Corp. v. Sharp Electronics Corp., 485 U.S. 717, 723 (1988) ("Certain categories of agreements, however, have been held to be per se illegal, dispensing with the need for case-by-case evaluation.") (emphasis added).

${ }^{18}$ Northwest Wholesale Stationers, Inc. v. Pacific Stationery and Printing Co., 472 U.S. 284, 289 (1985) ("This per se approach permits categorical judgments with respect to certain business practices that have proved to be predominantly anticompetitive.") (emphasis added); ; see also Illinois Tool Works Inc. v. Independent Ink, Inc., 547 U.S. 28 (2006) (referring to "the category of per se violations of the Sherman Act") (emphasis added); Texaco Inc. v. Dagher, 547 U.S. 1, (2006) ("the pricing decisions of a legitimate joint venture do not fall within the narrow category of activity that is per se unlawful under $\S 1$ of the Sherman Act") (emphasis added).

For example, the Court has opined that "[p]rice-fixing agreements between two or more competitors, otherwise known as horizontal price-fixing agreements, fall into the category of arrangements that are per se unlawful." Texaco Inc. v. Dagher, 547 U.S. 1, (2006) (emphasis added); Broadcast Music, Inc. v. Columbia Broadcasting System, Inc., 441 U.S. 1, 8 (1979) ("And agreements among competitors to fix prices on their individual goods or services are among those concerted activities that the Court has held to be within the per se category.") (emphasis added).

19 Leegin Creative Leather Products, Inc. v. PSKS, Inc., 127 S.Ct. 2705 (2007).
} 
reason treatment. ${ }^{20}$ In contrast to the per se rule, which eschews in-depth investigation, in rule of reason cases "the fact finder weighs all of the circumstances of a case in deciding whether a restrictive practice should be prohibited as imposing an unreasonable restraint on competition." 21 Under the rule of reason, courts take "into account a variety of factors, including specific information about the relevant business, its condition before and after the restraint was imposed, and the restraint's history, nature, and effect.",22 While the inquiry is searching and often wide-ranging, it remains "focuse[d] directly on the challenged restraint's impact on competitive conditions. . . . [T] he rule of reason does not support a defense based on the assumption that competition itself is unreasonable."23

\section{3. "Quick Look" and the Abbreviated Rule of Reason.}

The basic division of antitrust jurisprudence into the per se and rule of reason categories naturally raises the question of how to decide what conduct is in each box. Parties change behavior and characterizations in order to move conduct into one box or the other; we discuss a number of ways in which they do so in the next section. But there is also a problem we might think of as "meta-characterization": how does a court decide whether conduct whose legal status is disputed fits into the per se box or the rule of reason box? Logically, courts should think about the economic effects of the conduct in order to make the characterization decision. But to ask that question is necessarily to put

\footnotetext{
${ }^{20}$ See Continental T.V. v. GTE Sylvania Inc., 433 U.S. 36, (1977) (noting that the rule of reason is "applied for the majority of anticompetitive practices challenged under section 1 of the Act."); see also Leegin Creative Leather Products, Inc. v. PSKS, Inc., 127 S.Ct. 2705 (2007); State Oil Co. v. Khan, 522 U.S. 3, 10 (1997).

${ }^{21}$ Continental T.V., Inc. v. GTE Sylvania Inc., 433 U.S. 36, 49 (1977).

${ }^{22}$ State Oil Co. v. Khan, 522 U.S. 3, 10 (1997).

${ }^{23}$ National Soc'y of Professional Eng'rs v. United States, 435 U.S. 679, 688, 696 (1978).
} 
the conduct into the rule of reason box, since if the conduct was illegal per se we wouldn't inquire into the balancing of pro- and anticompetitive effects.

To avoid this conundrum, courts have developed a form of abbreviated or "quick look" rule of reason in an effort to characterize disputed conduct. ${ }^{24}$ The quick look approach allows a court to make a decision about whether a new form of conduct that appears to be facially anticompetitive should be illegal per se by asking the defendant to demonstrate any procompetitive justifications for the conduct. If the defendant can offer plausible economic reasons that the conduct is procompetitive, the court will put it in the rule of reason box and compare those justifications to the competitive harms. If they can't, the conduct is illegal per se.

Properly understood in this way, the quick look is an evidentiary rule that allows courts to make categorization decisions without a full-blown economic analysis that would eliminate the benefits of the per se rule. In fact, however, some courts have started to ossify "quick look" into an intermediate category of its own - a sort of abbreviated rule of reason. This seems the only explanation for the Court's decision in California Dental, for instance. ${ }^{25}$ There, the court rejected the Ninth Circuit's abbreviated inquiry into a price-fixing agreement among dentists, holding that a full rule of reason analysis was required. ${ }^{26}$ The entire debate makes no sense if "quick look" is, as originally intended, a way of deciding whether to put conduct into the per se or rule of reason boxes. Instead, the Court seems to have treated "quick look" as a box in and of itself. Indeed, the Supreme Court in its most recent foray into the issue referred to quick look in passing as

\footnotetext{
See, e.g., Cal. Dental Ass'n v. FTC, 526 U.S. 756 (1999).

California Dental Ass'n v. FTC, 526 U.S. 756 (1999).

Id. at 784-87.
} 
a third category of analysis. ${ }^{27}$ The result is that we end up not with two categories, but three: the per se rule, the rule of reason, and a middle category that is not quite per se illegality, but rather an option the defendant can convert to a rule of reason approach if they can make a certain showing.

\section{Categories or Continuum?}

Some antitrust commentators depict the relationship between per se and rule of reason analysis as "less a dichotomy than a continuum." 28 The Court has provided much ammunition for this position. ${ }^{29}$ The Court has gone so far as to assert that "properly understood, rule-of-reason analysis is not distinct from 'per se' analysis. On the contrary, agreements that are illegal per se are merely a species within the broad category of agreements that unreasonably restrain trade; less proof is required to establish their illegality, but they nonetheless violate the basic rule of reason." ${ }^{30}$ Such statements show a fundamental misunderstanding of basic antitrust principles. The per se rule and rule of reason analysis both attempt to define those agreements that fall in the category

27 See Texaco, Inc. v. Dagher, 126 S.Ct. 1276, 1279 (2006). Hovenkamp refers to the quick look approach as "an intermediate form of inquiry," rather than a procedure for deciding which of the two traditional forms of inquiry to apply. HERBERT HOVENKAMP, FEDERAL ANTITRUST POLICY: THE LAW OF COMPETITION AND ITS PRACTICE 265 (3d ed. 2005).

${ }^{28}$ ABA RULE OF REASON MONOGRAPH, supra note xx at 10 ("Once we see that the rule of reason can sometimes be quickly applied . . . without refined fact-finding, it becomes apparent that reasonableness inquiries are not so totally different from the per se approach ... [and] that the two are less a dichotomy than a continuum.”) (quoting 7 P. AREEDA, supra note 3, $11508 \mathrm{~b}$, at 408); Cavanagh, supra note at 826.

${ }^{29}$ United States v. Socony-Vacuum Oil Co., 310 U.S. 150, 218 (1940) (the methods are "best viewed as a continuum, on which the 'amount and range of information needed' to evaluate a restraint varies depending on how 'highly suspicious' and how 'unique' the restraint is."); see also ABA RULE OF REASON MONOGRAPH, supra note xx at 9 ("Antitrust scholars and the more recent Supreme Court decisions suggest that, rather than being a dichotomy, the traditional per se standard and comprehensive rule of reason analysis are more accurately viewed as representing opposite ends of a single continuum of antitrust analysis measuring the reasonableness of the challenged conduct.").

${ }^{30}$ U.S. v. U.S. Gypsum Co., 438 U.S. 422, 476 (1978). 
"unreasonable." But each approach takes a different tack. The per se rule is purely categorical: if a restraint falls in a per se class of contracts, the agreement is condemned outright. As Timothy Muris observed before the Court decided California Dental, the Supreme Court created a dichotomy where "per se rules are not part of the rule of reason analysis, and have no relationship to the reasonableness of a practice."31 Indeed, if "ruleof-reason analysis [were] not distinct from 'per se' analysis," as the Court asserts, hundreds of litigants would not be debating and dozens of federal judges would not be publicly agonizing over which mode of analysis to apply in each antitrust case.

The development of quick look analysis muddles the strict dichotomous categories of per se and rule of reason analysis. In California Dental, the first case in which the Court explicitly recognizes the existence of quick look analysis, the Justices attempt to bolster the commentators' suggestion that antitrust employs a continuum by way of the breathy confessional: "The truth is that our categories of analysis of anticompetitive effect are less fixed than terms like 'per se,' 'quick look,' and 'rule of reason' tend to make them appear." ${ }^{, 32}$ Such language reinforces the notion that a continuum is in operation. ${ }^{33}$ After California Dental, the D.C. Circuit opined that the Supreme Court had "backed away from any reliance upon fixed categories and toward a continuum." 34

\footnotetext{
${ }^{31}$ Timothy Muris, In Defense of Massachusetts Board, 66 ANTITRUST L.J. 773 (1998).

${ }^{32}$ California Dental Ass'n v. F.T.C., 526 U.S. 756, 779 (1999).

${ }^{33}$ See HOVENKAMP (“ANTITRUST ENTERPRISE"), supra note _ at 117 ("In its California Dental Association (CDA) decision the Supreme Court observed that there is no bright line between per se and rule of reason analysis, but rather a continuum.").

${ }^{34}$ Polygram Holding, Inc. v. F.T.C., 416 F.3d 29, 35 (D.C. Cir. 2005) ("It would be somewhat misleading, however, to say the "quick look" is just a new category of analysis intermediate in complexity between " per se " condemnation and full-blown "rule of reason" treatment, for that would suggest the Court has moved from a dichotomy to a trichotomy, when in fact it has backed away from any reliance upon fixed categories and toward a continuum.”).
} 
The Court's attempt to recharacterize its decades-old approach to antitrust analysis should not be understood as an abandonment of categorical decision-making, for several reasons. First, the continuum explanation is entirely inconsistent with the Court's earlier pronouncements, which it has declined to distinguish or disavow. Before acknowledging in 1999 the presence of the quick look method to prove unreasonability, the Court described its approach as utilizing "two complementary categories of antitrust analysis. In the first category are agreements whose nature and necessary effect are so plainly anticompetitive that no elaborate study of the industry is needed to establish their illegality-they are 'illegal per se.' In the second category are agreements whose competitive effect can only be evaluated by analyzing the facts peculiar to the business, the history of the restraint, and the reasons why it was imposed [i.e., rule of reason analysis]."35

There is no reasonable way to read this statement except as indicating that there are two distinct categories of antitrust analysis in section one cases: per se and rule of reason. When the Court muddled the categorical analysis in NCAA and Indiana Federation of Dentists, lower courts rationalized the Court's moves by divining the abbreviated rule of reason, or "quick look." But even after apparently blurring the distinction between per se and rule of reason, the Supreme Court subsequently steadfastly protected the per se categorical approach in FTC v. Superior Court Trial Lawyers ${ }^{36}$ and Palmer v. B.R.G. of Georgia. ${ }^{37}$ Interpreting the Court's quick look trajectory, the Federal Trade Commission reasoned that "[a]lthough there have been some oblique suggestions

\footnotetext{
${ }^{35}$ Professional Engineers, 435 U.S., at 692; see also F.T.C. v. Superior Court Trial Lawyers Ass'n, 493 U.S. 411 (1990) (quoting National Society of Professional Engineers).

${ }^{36} 493$ U.S. 411 (1990).

${ }^{37} 498$ U.S. $46(1990)$.
} 
in Supreme Court cases that perhaps the categories had merged, the Court later returned to distinguishing between per se and rule of reason categories ... [T] hese separate categories continue to serve valid enforcement purposes and, in any event, authoritative Supreme Court decisions continue to recognize the distinction. ${ }^{, 38}$ In short, even after disclaiming categorical analysis in favor of a flexible continuum, the Court itself continued to employ its per se-rule of reason structure in other cases. ${ }^{39}$

Perhaps this explains why so many lower courts continue to treat these as categories of per se and rule of reason analysis as dichotomous. Although some lower courts have suggested that the development of quick look analysis illustrates the move away from categories toward continua, ${ }^{40}$ even after recognition of the quick look, many courts continue to speak as though there are only two categories of antitrust analysis: per se and rule of reason. ${ }^{41}$ This is not surprising given that quick look is essentially a variant of rule of reason analysis, albeit abbreviated or truncated rule of reason.

\section{B. Characterizing restraints.}

Whether an agreement falls within a per se category - and the level of scrutiny that it will receive under whatever form of rule of reason the court applies - will be a function of a series of other categorizations. Not surprisingly, parties fight vigorously to

\footnotetext{
${ }^{38}$ Matter of California Dental Association, 121 F.T.C. 190, 299 (1996).

${ }^{39}$ See also Barry J. Brett \& Nancy C. Wallace, Sylvania and the Dual Distribution Dilemma, 26 N. Y. L. SCH. L. REV. 972, 973 (1981) (“Justice Powell in Sylvania made a point of preserving both the per se rule of United States v. Topco Associates for horizontal restraints, as well as per se rules for vertical price restraints.").

${ }^{40}$ Polygram Holding, Inc. v. Federal Trade Comm'n, 416 F.3d 29 (D.C. Cir. 2005)

${ }^{41}$ See, e.g., Flash Elec., Inc. v. Universal Music \& Video Dist. Corp., 312 F.Supp.2d 379, 385 (E.D.N.Y. 2004) ("Courts analyze the legality of such agreements using one of two frameworks: either the per se approach, or the "rule of reason." ") (citations omitted).
} 
have their conduct (or their adversary's conduct) classed on one side or the other of the following lines.

\section{Horizontal versus Vertical}

Antitrust law draws a fundamental distinction between so-called horizontal and vertical agreements. Horizontal agreements are contracts or conspiracies among competitors, firms at the same level in the distribution chain who we would expect to compete against each other in a free market. Vertical restraints are "those imposed by agreement between firms at different levels of distribution."

Determining whether the defendants in a section one case are in a horizontal or vertical relationship can be dispositive, because horizontal agreements are much more likely to be condemned as per se illegal while analogous vertical restraints are evaluated under the rule of reason. First, with respect to price restraints, horizontal agreements to fix or stabilize prices have been per se illegal for decades. ${ }^{43}$ By contrast, antitrust's treatment of vertical price restraints has evolved. The Supreme Court initially condemned vertical price-fixing as per se illegal in 1911 in Dr. Miles. This made agreements by a manufacturer to set the resale price of its products illegal as a matter of law. The Court pared back Dr. Miles' per se rule in 1997's State Oil v. Khan, holding that vertical agreements to set a maximum resale price should be evaluated under the rule of reason. ${ }^{44}$ Then, in its most recent antitrust opinion, Leegin, the Court reversed $\mathrm{Dr}$.

\footnotetext{
${ }^{42}$ Sharp Electronics, 485 U.S. at 730.

${ }^{43}$ Catalano, Inc. v. Target Sales, Inc., 446 U.S. 643 (1980); U.S. v. Socony-Vacuum Oil Co., 310 U.S. 150 (1940); U.S. v. Trenton Potteries Co., 273 U.S. 392 (1927).

${ }^{44}$ State Oil Co. v. Khan, 522 U.S. 3 (1997).
} 
Miles outright, rendering all vertical price agreements subject to rule of reason analysis. ${ }^{45}$ As a result, horizontal price restraints fall in the per se category and vertical ones do not.

Second, the legality of territorial restraints is a function of whether courts conceive the agreement to be horizontal or vertical in nature. Territorial restraints exist when sellers are assigned exclusive territories in which competition has been limited in some form. Horizontal market division, in which competitors allocate exclusive geographic markets to each other, is per se illegal. ${ }^{46}$ Following 1967's Schwinn opinion, vertical territorial restraints were also condemned as illegal per se. ${ }^{47}$ But a decade later, the Court reversed course in Sylvania, ${ }^{48}$ holding that territorial restrictions imposed vertically are evaluated under the rule of reason. As the Court explicitly reaffirmed the per se rule against similar horizontal restraints, ${ }^{49}$ Sylvania marked a turning point in section one jurisprudence and increased the stakes of the horizontal-vertical categorization considerably.

Third, courts often characterize concerted refusals to deal as either horizontal or vertical in nature in order to determine whether the group boycott warrants per se condemnation. Those boycotts that "originate among the horizontal competitors" are

45 Leegin Creative Leather Prods. v. PSKS, 127 S.Ct. 2705 (2007).

${ }^{46}$ Palmer v. BRG of Georgia, Inc., 498 U.S. 46 (1990) (horizontal agreement to divide geographic markets was "unlawful on its face"); U.S. v. Topco Associates, Inc., 405 U.S. 596 (1972).

${ }^{47}$ U. S. v. Arnold, Schwinn \& Co., 388 U.S. 365 (1967).

${ }^{48}$ Continental T. V., Inc. v. GTE Sylvania Inc., 433 U.S. 36 (1977)

49433 U.S. at 58 n.28; see also Palmer v. BRG of Georgia, Inc., 498 U.S. 46 (1990); David E. Weisberg, Continental TV v. GTE Sylvania: Implications for Horizontal, as Well as Vertical, Restraints on Distributors, 33 BUS. LAWYER 1757, 1761 (1978) ("Thus, the Court takes pains to contrast the vertical nature of the restraints in Continental $T V$ with the horizontal restraints in Tорсо."). 
more likely to be treated as per se illegal. ${ }^{50}$ In contrast, concerted refusals to deal deemed to be vertical receive full rule of reason analysis. ${ }^{51}$

Finally, the distinction between horizontal and vertical restraints sometimes drives policy proposals in antitrust. For example, in the debate over the role of contribution in antitrust claims, some scholars argued that the availability of contribution should be a function of whether the challenged restraints was horizontal or vertical. ${ }^{52}$

\section{Naked versus Ancillary}

Another distinction that courts sometimes employ in determining whether a challenged agreement goes in a per se category is whether the restraint is ancillary or naked. Federal courts have reasoned that they "must distinguish between 'naked' restraints, those in which the restriction on competition is unaccompanied by new production or products, and 'ancillary' restraints, those that are part of a larger endeavor whose success they promote. ${ }^{, 53}$ Naked restraints are essentially per se illegal. ${ }^{54}$ Ancillary restraints are evaluated under the rule of reason and generally survive it. ${ }^{55}$

\footnotetext{
${ }^{50}$ See Flash Elec., Inc. v. Universal Music \& Video Dist. Corp., 312 F.Supp.2d 379, 388 n.4 (E.D.N.Y. 2004).

${ }^{51}$ See infra notes _ to _ and accompanying text (discussing the horizontal versus vertical debate in group boycott cases).

${ }^{52}$ Donald J. Polden \& E. Thomas Sullivan, Contribution and Claim Reduction in Antitrust Litigation: A Legislative Analysis, 20 HARV. J. ON LEGIS. 397, 416 (1983) ("Moreover, vertical and horizontal arrangements should be distinguished, as they are in large part in standards of antitrust liability, because beneficial effects often accompany vertical nonprice restrictions, and the harshness of the no-contribution rule may unnecessarily inhibit otherwise procompetitive conduct.").

${ }^{53}$ Polk Bros., Inc. v. Forest City Enters., Inc., 776 F.2d 185, 188-89 (7th Cir. 1985)).

${ }^{54}$ See ABA Antitrust Section, Monogram No. 23, The Rule of Reason (1999) ("In the case of certain agreements, principally those directly affecting price or output, the adverse effect on competition is readily apparent. These agreements are variously termed 'naked restraints,' facially anticompetitive' or 'inherently suspect."').

55 ABA Antitrust Section, Monogram No. 23, The Rule of Reason, 124 (1999)

("Ancillary restraints are judged under the rule of reason and are lawful if reasonably necessary
} 
Some courts have suggested that "naked restrictions" that do "not clearly fit within a per se category" should receive quick look scrutiny, ${ }^{56}$ though it is unclear whether that quick look will lead to per se classification or to treatment as an intermediate third category. Regardless, for a restraint to be categorized as "naked" is a fair harbinger of impending condemnation.

\section{Voluntary Versus Coerced Restraints}

In some circumstances courts classify the legality of conduct on the basis of whether an agreement was made voluntarily or was coerced by a firm with market power. An example is the antitrust (and patent misuse) treatment of package licenses: agreements to purchase not just a single patent license but to license a block of patents together in a single package. In 1950, the Supreme Court held that the package licensing of hundreds of patents relating to radio technology was lawful, because licensees wanted the package so they could clear all the rights they needed to manufacture their products. ${ }^{57}$ By 1969 , however, the Court held the same package license by the same patent holding company

to achieve the success of a legitimate joint venture.")(citations omitted); see also Polk Bros., Inc. v. Forest City Enters., Inc., 776 F.2d 185, 190 (7th Cir. 1985) ("The reason for distinguishing between 'ancillary' and 'naked' restraints is to determine whether the agreement is part of a cooperative venture with prospects for increasing output. If it is, it should not be condemned per se."); Rothery Storage \& Van Co. v. Atlas Van Lines, Inc., 792 F.2d 210, 224 (D.C. Cir. 1986) ("To be ancillary, and hence exempt from the per se rule, an agreement must be subordinate and collateral to a separate, legitimate transaction. The ancillary restraint is subordinate and collateral in the sense that it serves to make the main transaction more effective in accomplishing its purpose."). See also SCFC, 36 F.3d at 970 (quoting Rothery); Polk Bros., 776 F.2d at 189 ('A restraint is ancillary when it may contribute to the success of a cooperative venture that promises greater productivity and output.').

${ }^{56}$ See Bogan v. Hodgkins, 166 F.3d 509, 514 n. 6 (2d Cir. 1999).

57 Automatic Radio Mfg. Co. v. Hazeltine Res., Inc., 339 U.S. 827 (1950). 
per se illegal because the defendants complained that they were forced to take licenses to patents they did not want or need. ${ }^{58}$

The Federal Circuit adopted this distinction between voluntary and coerced package licenses in Engel v. Lockformer. ${ }^{59}$ In Engel, the accused infringer had signed a licensing agreement with the patentee for use of the patented system for connecting sheet metal ducts together. The agreement called for calculation of royalties based in part on the number of "corner connectors" used by the licensee; these components were not covered by the patent. The court pointed out that this was a convenient way to calculate royalties, and noted that the licensee "voluntarily agreed to the royalties provisions," and that the licensor had not "used its market power to shoehorn [the licensee] into license agreement that forced [it] to purchase unpatented items . ..,60 As a result, it found no coercion and hence no misuse. Had the licensee been coerced, however, the court suggested that the royalty provision might have been invalid. ${ }^{61}$

While in theory such a distinction might make sense, as a "tie" results only from a coercive connection, ${ }^{62}$ in practice it is likely to prove difficult if not impossible to distinguish voluntary from involuntary agreements. Contract law has rightly shied away from inquiring into whether one party "wanted to" agree to a contractual provision in all but the most egregious cases. It is enough to show that they did agree. The Court's distinction will likely encourage self-serving testimony by both parties long after the fact

\footnotetext{
58 Zenith Radio Corp. v. Hazeltine Res., Inc., 395 U.S. 100 (1969).

5996 F.3d 1398 (Fed. Cir. 1996).

6096 F.3d at 1408

61 Accord American Securit Co. v. Shatterproof Glass Corp., 268 F.2d 769 (3d Cir. 1959) ("The protection, or monopoly, which is given to the first patent stops where the monopoly of the second begins. Whatever may be the asserted reason or justification of the patent owner, if he compels a licensee to accept a package of patents or none at all, he employs one patent as a lever to compel the acceptance of a license under another. Equity will not countenance such a result."). 62 See infra notes ___ a and accompanying text.
} 
of the agreement itself. Further, it will encourage strategic behavior by licensors, who may be expected to include "voluntariness" clauses in future contracts. ${ }^{63}$

Interestingly, in its most recent treatment of the package licensing issue, the Federal Circuit eschewed any discussion of the voluntariness of the license, and indeed rejected application of the per se rule altogether. In Philips Corp. v. International Trade Comm ' $n,{ }^{64}$ the court rejected the "hornbook law" that mandatory package licensing was patent misuse as "not supported by precedent or reason." Philips makes no effort to distinguish Zenith or Engel even though it seems flatly to reject their voluntariness analysis. Despite this omission, and the resulting conflict in Federal Circuit caselaw, there is some reason to believe Philips signals an inclination on the court to replace the unworkable voluntariness standard with a more economically reasonable alternative. Something similar occurs in copyright law. The practice of "block booking" requiring a TV station or movie theater to take a package of shows to exhibit - is illegal per se. ${ }^{65}$ By contrast, it is perfectly legal to enter into voluntary agreements to license not just one but many shows. This distinction is problematic for the same reasons as the patent distinction, but like the patent distinction, it seems to drive the outcome.

63 In Leesona Corp. v. Varta Batteries, 522 F. Supp. 1304, 1341 (S.D.N.Y. 1981), the court set some standards for determining whether such an agreement is in fact coerced. The court looked "to see whether the license condition was the result of good faith bargaining between the parties or was imposed on the licensee by the patent holder and whether the licensee raised objections that were overridden by the licensor."

64424 F.3d 1179 (Fed. Cir. 2005).

65 See, e.g., United States v. Loew's, Inc., 371 U.S. 38 (1962)While the per se rule against block booking is old, and arguably dates from a prior era of hostility to IP licensing that no longer exists, modern courts have reaffirmed the per se rule. See, e.g., MCA Television Ltd. v. Public Interest Corp., 171 F.3d 1265 (11 ${ }^{\text {th }}$ Cir. 1999). 
In these cases, courts have created sharp categories - voluntary and coerced package licenses - that they use to divide cases between per se illegality and the rule of reason.

\section{Unilateral versus Concerted Restraints}

Perhaps the most fundamental distinction in antitrust law is between unilateral and concerted restraints. This distinction is one of the few that has a statutory basis; section 1 of the Sherman Act governs only "contracts, combinations or conspiracies" in restraint of trade, while unilateral actions are given more favorable treatment under section 2. This distinction is significantly, though not perfectly, correlated with the line between the rule of reason and per se illegality: claims involving unilateral restraints are almost all evaluated under a rule of reason-type approach where the courts weighs the anti- and pro-competitive effects of the challenged conduct, while many (though by no means all) concerted acts are illegal per se.

\section{Obsolete Categories}

\section{a. Price versus Nonprice}

Until recently, section one jurisprudence maintained a critical distinction between price and non-price restraints for many types of conduct. As noted, Dr. Miles condemned vertical price restraints as per se illegal. When Sylvania removed vertical non-price restraints from the per se category, this meant that vertical price and non-price restraints received fundamentally different treatment. ${ }^{66}$ Plaintiffs sought to characterize the

\footnotetext{
${ }^{66}$ See Barry J. Brett \& Nancy C. Wallace, Sylvania and the Dual Distribution Dilemma, 26 N. Y. L. SCH. L. REV. 972, 973 (1981) ("Justice Powell in Sylvania made a point of preserving both the
} 
defendants' agreement as price-related and defendants scrambled to present their restraints as non-price in nature. ${ }^{67}$ In its June 2007 Leegin opinion, a five-member majority of the Court asserted that there was "little economic justification for the current differential treatment of vertical price and nonprice restraints. ${ }^{\prime 68}$ With Leegin's reversal of Dr. Miles, courts will analyze all vertical restraints under the rule of reason. The pricenon-price categorization process should cease, at least for vertical restraints.

\section{b. Maximum versus Minimum Pricing}

In the context of horizontal price agreements, courts make no distinction based on whether the prices set are characterized as minimum or maximum prices. The minimummaximum distinction once had resonance in vertical price-fixing cases. While the Court's first opinion treating resale price maintenance as per se illegal involved the fixing of minimum prices, ${ }^{69}$ the Court later expanded this to a prohibition on maximum resale price maintenance as well. ${ }^{70}$ The Court then backtracked, holding that vertical maximum price fixing should be evaluated under rule of reason. ${ }^{71}$ This made the distinction between vertically-set minimum and maximum prices critical - the latter fell in a per se category and the former did not. However, this categorical distinction was to last but a decade, as the recent Leegin decision brought minimum resale price maintenance within the rule of

per se rule of United States v. Topco Associates for horizontal restraints, as well as per se rules for vertical price restraints.”).

${ }^{67}$ HOVENKAMP (“ANTITRUST ENTERPRISE"), supra note xx at 191 ("Lawyer and judicial resources are wasted in disputes about whether a particular restraint falls into the "price" or "nonprice" category. But this dispute has taken center stage in vertical restraints cases because price restraints are unlawful per se, while virtually all nonprice restraints are legal.").

${ }^{68}$ Leegin Creative Leather Products, Inc. v. PSKS, Inc., 127 S.Ct. 2705 (2007).

${ }^{69}$ Dr. Miles Medical Co. v. John D. Park \& Sons Co., 220 U.S. 373 (1911)

${ }^{70}$ Albrecht v. Herald Co., 390 U.S. 145, 152-54 (1968).

${ }^{71}$ State Oil Co. v. Kahn, 522 U.S. 3 (1997) (overruling Albrecht v. Herald Co., 390 U.S. 145, 152-54 (1968)). 
reason. ${ }^{72}$ While Leegin renders the maximum-minimum categorization process irrelevant today, this evolution reinforces the critical distinction between horizontal and vertical restraints. Horizontal maximum price-fixing is per se illegal, while vertical maximum price-fixing is evaluated under the rule of reason and essentially legal.

\section{Problems with Reliance on Categorical Analysis.}

As long as antitrust maintains differential rules, litigants will debate categorization and companies will try to conform their conduct to the more lenient box. While some of this discussion may help inform the antitrust analysis, courts and practitioners have often gone overboard. In many cases, courts spend more time determining the category than analyzing the effects of the restraint. This section highlights several of the current problems with categorical analysis in antitrust jurisprudence.

\section{A. Shifting Categories}

One of the problems with categorical analysis is that the boundaries of categories shift without logic or warning. The Supreme Court recently asserted in Leegin, "the boundaries of the doctrine of per se illegality should not be immovable."73 This is true, but as scholars noted even before the development of quick look, "the line between application of the per se rule and the rule of reason has become blurred to the point that these analytical tools are often indecipherable." 74 The evolution of quick look analysis has made matters worse, as confusion over whether a challenged restraint falls within the

\footnotetext{
${ }^{72}$ Leegin Creative Leather Products, Inc. v. PSKS, Inc., 127 S.Ct. 2705 (2007).

${ }^{73}$ Leegin Creative Leather Products, Inc. v. PSKS, Inc., 127 S.Ct. 2705, 2720-21 (2007).

${ }^{74}$ ABA RULE OF REASON MONOGRAPH, supra note $\mathrm{xx}$ at 10.
} 
"quick look" or requires "full-blown rule of reason analysis" introduces significant uncertainty into antitrust litigation. $^{75}$

The categorical analysis practiced by the Supreme Court is premised on shifting, ill-defined boxes. This makes antitrust analysis unprincipled and unpredictable. This section reviews antitrust categories that appeared stable and then shifted, leaving in their wake categories of restraints that are nominally per se but, in reality, much more complicated.

\section{Price-Fixing}

Horizontal price-fixing represents the epitome of per se illegal conduct. It is the oldest and least controversial per se category. But the contours of what constitutes pricefixing have expanded and contracted in a manner that reduces precision and predictability. The Court early on signaled an unwillingness to consider as a defense an argument by cartels that they had set a reasonable price. ${ }^{76}$ In its first use of the "per se" terminology, the Court in Socony-Vacuum held that "a combination formed for the purpose and with the effect of raising, depressing, fixing, pegging, or stabilizing the price of a commodity in interstate or foreign commerce is illegal per se." ${ }^{, 77}$ The concept of price-fixing expanded to include agreements among competitors to eliminate discounts and the extension of credit $^{78}$ as well as agreements to set maximum prices. ${ }^{79}$ Even as the category of per se illegal horizontal price-fixing grew, the concept remained relatively

\footnotetext{
${ }^{75}$ Schwartz v. Dallas Cowboys Football Club, Ltd., 157 F.Supp.2d 561 (E.D. Pa. 2001).

${ }^{76}$ See U.S. v. Trenton Potteries Co., 273 U.S. 392 (1927); but see Appalachian Coals v. U.S., 288 U.S. 344 (1933).

${ }^{77}$ U.S. v. Socony-Vacuum Oil Co., 310 U.S. 150, 223 (1940)

${ }^{78}$ Catalano, Inc. v. Target Sales, Inc., 446 U.S. 643 (1980).

${ }^{79}$ Arizona v. Maricopa County Medical Soc., 457 U.S. 332 (1982).
} 
clear: antitrust law condemns cartel arrangements in which competitors set price collectively rather than letting competition determine price and output.

That clarity blurred with 1979 's $B M I$ decision. ${ }^{80}$ In $B M I$, the Court considered the legality of blanket licenses in which performing rights societies aggregated the copyrighted works of thousands of composers and licensed the works to television stations for one fee. The blanket licenses fixed prices. They also reduced transactions costs considerably, essentially creating a new product, which was apparently desired by most TV stations. Instead of saying that the blanket licenses did not represent a cartel arrangement in form or function, the Court opined that "[a]s generally used in the antitrust field, 'price fixing' is a shorthand way of describing certain categories of business behavior to which the per se rule has been held applicable.... Thus, it is necessary to characterize the challenged conduct as falling within or without that category of behavior to which we apply the label "per se price fixing.",81 The language of $B M I$ suggests that the per se rule had ceased to be an analytical approach and had instead become a legal conclusion based on some sort of functional market analysis.

After $B M I$, price-fixing is a less clear category. The Court's language had the unfortunate effect of muddling the category, with the Court essentially saying that "fixing prices is not price fixing." While the Court was correct to conclude that blanket licensing should not, in and of itself, fall in the per se category, the Court did little to define the contours of this - the most critical - per se category and explain why blanket licensing was different. As a result, the per se rule lost some vital predictability.

\footnotetext{
${ }^{80}$ Broadcast Music, Inc. v. Columbia Broadcasting System, Inc., 441 U.S. 1 (1979).

${ }^{81}$ Id. at 9.
} 
The Court blurred the contours of the per se illegal price-fixing category further in its Dagher opinion. In Dagher, the plaintiffs challenged the legality of joint venture members' setting a price for their respective branded gasoline products. The Court held that the agreement was not per se illegal because it took place in the context of a "legitimate joint venture" - one that had been approved by the FTC and the relevant agencies of four states - in which the former competitors cooperated. ${ }^{82}$ The Court reasoned that "[a]s a single entity, a joint venture, like any other firm, must have the discretion to determine the prices of the products that it sells, including the discretion to sell a product under two different brands at a single, unified price." ${ }^{, 83}$ But the Court's reasoning hinges on the characterization of Equilon "as a single entity." If Equilon is to be treated as a single entity, then any debate about the per se rule versus rule of reason analysis is completely superfluous - a single entity cannot violate section one as a matter of law, because section one requires an agreement between separate entities, and unilateral conduct under section two is never subject to per se condemnation. Justice Thomas' confusion on basic antitrust principles leaves it unclear what the Court is doing with the per se rule in this case.

The parameters of the per se category are also distorted by the Court's utter failure to define what it means by "legitimate joint venture," which is the entire basis for excluding the oil companies' agreement from per se condemnation. When is a joint venture "legitimate" such that it falls outside of the per se category? The Court gives no criteria; indeed, it "presume[s] for purposes of these cases that Equilon is a lawful joint

\footnotetext{
${ }^{82}$ Texaco Inc. v. Dagher, 547 U.S. 1 (2006) (“[T]he pricing decisions of a legitimate joint venture do not fall within the narrow category of activity that is per se unlawful under $\S 1$ of the Sherman Act...").

${ }^{83}$ Texaco, Inc. v. Dagher, 547 U.S. 1 (2006).
} 
venture." 84 But if legality turns on the defendant being a "legitimate joint venture," then Justice Thomas simply presumed the defendant's agreement did not violate the Sherman Act. Justice Thomas quotes $B M I$ for the proposition that "[j]oint ventures and other cooperative arrangements are ... not usually unlawful, at least not as price-fixing schemes, where the agreement on price is necessary to market the product at all." ${ }^{, 85}$ But in $B M I$, cooperation was needed to create the new product, a blanket license. In Dagher, there is no hint in the Court's opinion that this joint venture was necessary to create gasoline, hardly a new product.

The Court's treatment of the per se and rule of reason analyses as separate legal theories creates further problems. The Court concludes that Equilon's price-fixing cannot be condemned as per se illegal and it chastises the plaintiff, admonishing them that they "should have challenged [Equilon's price unification policy] pursuant to the rule of reason. ${ }^{\prime 86}$ However, it precluded them from arguing that the restraint violated section one under rule of reason analysis because they did "not put forth a rule of reason claim." 87 On remand, the Ninth Circuit was compelled to affirm the district court's summary judgment against the plaintiffs, who were never allowed to make a rule of reason argument. ${ }^{88}$ The Court's reasoning is seriously flawed. The per se rule and rule of reason are modes of analysis, not separate causes of action. Just because one mode of analysis may not be appropriate does not preclude condemnation under another test. The

\footnotetext{
${ }^{84}$ Dagher, 547 U.S. at

${ }^{85}$ Dagher, 547 U.S. at __ (quoting Broadcast Music, 441 U.S. 1, 23 (1979)).

${ }^{86}$ Texaco, Inc. v. Dagher, 547 U.S. 1 (2006).

${ }^{87}$ Dagher, 547 U.S. at

${ }^{88}$ Dagher v. Saudi Refining Inc., 466 F.3d 1120 (9th Cir. 2006) (affirming summary judgment against plaintiffs).
} 
cause of action (an unreasonable restraint of trade) and the remedy (trebled damages and appropriate injunction relief) are exactly the same.

The Court's approach creates perverse and inefficient incentives. Following BMI and Dagher, plaintiffs may be less certain whether conduct that appears to be per se illegal will be held so by courts. It is hard to guess correctly; after all, the Ninth Circuit had held that Texaco and Shell Oil's pricing conduct in Dagher was per se illegal. ${ }^{89}$ Thus, in the wake of Dagher, savvy plaintiffs will not rely solely on per se arguments. Rather, they will develop cases under both per se and rule of reason theories. But if a plaintiff has to argue both per se and rule of reason from the start in order to prevent the court from changing the mode of analysis and refusing to allow the plaintiff leave to pursue a formerly per se case under a rule of reason analysis, then every plaintiff will have to go to the expense of pleading and developing a rule of reason case. ${ }^{90}$ This undermines the efficiency purpose of the per se rule.

\section{Group Boycotts}

Initially, the Supreme Court declared group boycotts to be per se illegal. In Klor's Inc. v. Broadway-Hale Stores, Inc., ${ }^{91}$ Klor's, a San Francisco department store, sued its down-the-street rival for convincing several manufacturers of consumer electronics and other household appliances to join a conspiracy to cease supplying Klor's with their products. Without using the precise words "per se illegality," the Court nonetheless articulated a per se rule against such concerted action: "Group boycotts, or

\footnotetext{
${ }^{89}$ Dagher, 547 U.S. at (citing Dagher v. Saudi Refining, Inc., 369 F.3d 1108, 1116 (2004))

${ }^{90}$ While this occurred before Dagher to some degree, the Court's approach in Dagher can only exacerbate the problem.

91359 U.S. 207 (1959).
} 
concerted refusals by traders to deal with other traders, have long been held to be in the forbidden category. They have not been saved by allegations that they were reasonable in the specific circumstances..." ${ }^{.92}$ That is the essence of per se illegality: the conduct falls in a "forbidden category" so courts denounce it without considering the reasonableness of the specific restraint at issues because it is condemned categorically. Lower courts interpreted Klor's as putting group boycotts in the per se category. ${ }^{93}$

The Court later began to erode the contours of the per se category for group boycotts. In Northwest Wholesale Stationers, Inc. v. Pacific Stationery and Printing Co., ${ }^{94}$ a case involving a member firm's expulsion from a buyers' cooperative, the Court cast doubt on this per se categorization. First, after noting that “' $[\mathrm{g}] \mathrm{roup}$ boycotts” are often listed among the classes of economic activity that merit per se invalidation under $\S$ 1," the Court hedged by saying, "Exactly what types of activity fall within the forbidden category is, however, far from certain. ${ }^{.95}$ The Court even quoted Lawrence Sullivan's famous observance that "there is more confusion about the scope and operation of the per se rule against group boycotts than in reference to any other aspect of the per se doctrine, ${ }^{, 96}$ apparently without appreciating that it was the source of the confusion.

Second, the Court attempted to define the boundaries of the per se category for group boycotts. As the Ninth Circuit aptly summarized, "Northwest Wholesale identified three characteristics as indicative of per se illegal boycotts: (1) the boycott cuts off access to a supply, facility, or market necessary to enable the victim firm to compete; (2) the

\footnotetext{
${ }^{92}$ Id. at 212.

${ }^{93}$ Walker Distributing Co. v. Lucky Lager Brewing Co., 323 F.2d 1, 7 (9th Cir. 1963) ("Group boycotts are just as illegal under the Sherman Act as group price fixing.") (citing Klor's, Inc. v. Broadway-Hale Stores, Inc., 359 U.S. 207, 212 (1959)).

${ }^{94} 472$ U.S. 284 (1985)

${ }^{95} 472$ U.S. at 293-94.

${ }^{96}$ Id. (quoting Lawrence Sullivan, Law of Antitrust 229-230 (1977).)
} 
boycotting firm possesses a dominant market position; and (3) the practices are not justified by plausible arguments that they enhanced overall efficiency or competition."97 Defining the parameters of the per se category in this fashion is peculiar because market power and efficiency justifications are the hallmarks of rule of reason analysis. Under this legal test for group boycotts, courts must apply the rule of reason in order to determine whether the per se rule applies. In short, this approach ceases to be per $\mathrm{se}^{98}$ if group boycotts are subject to per se condemnation only after courts have performed a modified rule of reason inquiry.

Accordingly, it might be tempting to conclude that group boycotts are analyzed under the rule of reason, despite the Court's imposition of a per se label. This would not be unprecedented. For example, the Court continues to refer to tying arrangements as per se illegal despite the fact that tie-ins are not subject to categorical condemnation and receive treatment that is, in reality, a structured rule of reason analysis. ${ }^{99}$

Yet courts still do sometimes condemn group boycotts without elaborate inquiry and without permitting the defendants to proffer any defense and without marching through the Northwest Wholesale factors. ${ }^{100}$ For example, in Federal Trade Commission v. Superior Court Trial Lawyers Association, ${ }^{101}$ in which trial lawyers boycotted working as court-appointed counsel for indigent defendants unless the D.C. government increased

\footnotetext{
${ }^{97}$ Hahn v. Oregon Physicians' Serv., 868 F.2d 1022, 1030 (9th Cir. 1988).

98 Daralyn J. Durie \& Mark A. Lemley, The Antitrust Liability of Labor Unions for Anticompetitive Litigation, 80 Cal. L. Rev. 757, 774 (1992) ("A per se rule that applies only when a defendant has market power and cannot show procompetitive effects is no per se rule at all.").

${ }^{99}$ See infra notes _ to _ and accompanying text.

100 For an example of a decision that applied Northwest Wholesale and still found the per se rule to govern, see Consumers Warehouse Center, Inc. v. Intercounty Appliance Corp., _ F. Supp. 2d , 2007 WL 922423 (E.D.N.Y. Mar. 26, 2007).

${ }^{101} 493$ U.S. 411 (1990).
} 
compensation, the Supreme Court condemned the defendants' boycott as per se illegal without even mentioning Northwest Wholesale. In the main text of its opinion, the Court fails to provide any meaningful guidance as how to distinguish between per se illegal group boycotts and those analyzed under the rule of reason. This has led to great confusion for lower federal courts. ${ }^{102}$ However, the Court does attempt to justify its per se label in a footnote where, in response to Justice Brennan's dissent, the majority "emphasize[s] that this case involves not only a boycott but also a horizontal price-fixing arrangement-a type of conspiracy that has been consistently analyzed as a per se violation for many decades."103 This highlights yet another problem with categorization: the Supreme Court's characterization of the lawyers' agreement as a boycott seems odd. The agreement seems more akin to horizontal price-fixing, which the Court seems to acknowledge in its footnote. If this justifies the per se condemnation, why categorized the conduct as a group boycott in the first place?

Group boycotts remain subject to categorical condemnation, but the category's parameters are imprecise. Group boycotts are per se illegal, but the Court declines to define what it means by the term. ${ }^{104}$ Even when the challenged conduct is a boycott, the Court in a classic understatement has opined that refusals to deal "are not a unitary

\footnotetext{
${ }^{102}$ See, e.g., Flash Elec., Inc. v. Universal Music \& Video Dist. Corp., 312 F.Supp.2d 379, 387 (E.D.N.Y. 2004) ("The Second Circuit has echoed that caution, while noting that " $[t]$ he scope of the per se rule against group boycotts is a recognized source of confusion in antitrust law.") (citing Bogan, 166 F.3d at 515.).

${ }^{103}$ Id. at n. 19.

${ }^{104}$ See F.T.C. v. Indiana Federation of Dentists, 476 U.S. 447, 458 (1986) (“Although this Court has in the past stated that group boycotts are unlawful per se, we decline to resolve this case by forcing the Federation's policy into the "boycott" pigeonhole and invoking the per se rule.").
} 
phenomenon."105 Yet if group boycotts are not unitary, it seems inappropriate for the Court to treat them as a category of per se illegal restraint. Ultimately, boycott litigation can devolve into debates about categorization instead of an analysis of anticompetitive effects.

\section{Information Exchanges}

Antitrust law is understandably nervous whenever competitors get together in a room and exchange information. Information exchange, especially information about prices and output, can facilitate the formation of a cartel and also help cartelists detect and prevent cheating. At the same time, trade associations can also serve valuable procompetitive (or at least competitively neutral) purposes. ${ }^{106}$

Antitrust law has tried to accommodate these competing concerns by drawing rough lines between exchanges of price information, which they often treat as illegal per se, and exchanges of other forms of information, which are subject to the rule of reason. ${ }^{107}$ Taken in the abstract, this category approach makes some sense, because it targets the per se rule at the category of cases that seems most likely to cause competitive harm.

The problem is that the value of information exchanges has changed over time. An example involves standard-setting organizations (SSOs), which were virtually unknown in the 1920s when the information exchange rules were created, but which are

105 St. Paul Fire \& Marine Ins. Co. v. Barry, 438 U.S. 531, 543 (1978).

106 See, e.g., David J. Teece, Information Sharing, Cooperation, and Antitrust, 62 Antitrust L.J. 465 (1994).

107 Compare Maple Flooring Mfrs. Ass'n v. United States, 268 U.S. 563 (1925) with Eastern States Retail Lumber Dealers Ass'n v. United States, 234 U.S. 600 (1914) (exchange of information supporting a boycott of competitors at trade association meeting violated section 1); American Column \& Lumber Co. v. United States, 257 U.S. 377 (1921). 
now ubiquitous in the information technology industries. SSOs serve valuable procompetitive purposes, particularly in network industries where products must work together. ${ }^{108}$ Further, the experience of SSOs with intellectual property (IP) rights suggests that organizations will often need to discuss and even agree on the price at which patent owners will license rights covering the standard, or else they will be adopting standards without any idea of whether they will be infringing a patent and thus without knowing the total cost of that standard. ${ }^{109}$ The head of the FTC has recently recognized the need for price information exchange in SSOs, suggesting that that particular form of price information should be subject to the rule of reason rather than the per se rule. ${ }^{110}$ We think the FTC's approach makes sense, and that SSOs should be able to exchange price information about IP licenses without facing per se liability. ${ }^{111}$ The category distinction between price and non-price information exchange made sense when it was developed, but it did not consider the complexities of modern technology or the specific context of patents covering standards. The proper rule in the modern world shouldn't draw the sharp distinction that made sense in the 1920s.

108 See, e.g., Mark A. Lemley, Intellectual Property Rights and Standard-Setting Organizations, 90 Cal. L. Rev. 1889 (2002); Mark A. Lemley, Antitrust and the Internet Standardization Problem, 28 Conn. L. Rev. 1041 (1996).

109 For a discussion, see, e.g., Mark A. Lemley, Ten Things To Do About Patent Holdup of Standards (And One Not To), 48 B.C. L. Rev. 149 (2007).

110 Deborah Platt Majoras, Recognizing the Procompetitive Potential of Royalty Discussions in Standard Setting, http://www.ftc.gov/speeches/majoras/050923stanford.pdf (September 23, 2005).

111 Cases are split on this question right now. See, e.g., Addamax Corp. v. Open Software Found., 888 F. Supp. 274, 281, 284-85 (D. Mass. 1995), aff'd 152 F.3d 48 (1st Cir. 1998) (finding that an antitrust challenge to an SSO could proceed to trial under the rule of reason, but ultimately finding no liability); Sony Elec. v. Soundview Tech., 157 F. Supp. 2d 180, 183 (D. Conn. 2001); cf. In re American Soc'y of Sanitary Eng'g, 106 F.T.C. 324, 329 (1985) (consent decree forbidding SSO from rejecting proposed standards solely because they were patented). For a discussion of these cases, see 2 Hovenkamp et al., IP and Antitrust $\S 35.6 \mathrm{c}$. 


\section{B. Categories Subject to Manipulation.}

Categories may make antitrust analysis more step-wise and orderly, but at a significant price. Even categories that seem fixed in antitrust law may change from case to case because they are subject to manipulation by plaintiffs who want to put conduct in a forbidden box and defendants who want it in a box that receives more lenient treatment.

\section{Horizontal versus Vertical}

The purpose of distinguishing horizontal and vertical restraints is judicial efficiency. If a restraint is horizontal, then courts are more likely to condemn it under the per se rule. This saves time and resources because such horizontal restraints are likely or almost always likely to reduce competition in a manner that antitrust cares about, while vertical restraints often serve legitimate business purposes. However, given the consequences of a restraint being labeled horizontal, the focus of antitrust litigation often shifts away from whether or not the restraint is unreasonable to whether the restraint is properly categorized as horizontal. This section examines antitrust scenarios in which the amount of time and energy invested in debating what label to apply to the defendants would have been better spent determining the actual competitive effects of the restraint at issue.

\section{a. Cooperatives}

One example of unnecessary debate over whether conduct is appropriately characterized as vertical or horizontal involves the restraints imposed by cooperative associations and joint ventures. The process of categorizing relationships among 
members of a cooperative association began in earnest with 1967's Sealy decision. ${ }^{112}$

Sealy involved a joint venture that licensed mattress manufacturers to make and sell mattresses and other bedding products under the Sealy trademark. Each of the approximately 30 licensees was allotted an exclusive territory. ${ }^{113}$ The government brought an action against Sealy, challenging its licensing scheme as a "conspir[acy] to allocate mutually exclusive territory among its manufacturers.",114

To determine whether this allocation of exclusive territories violated section one of the Sherman, the Court felt it necessary to first categorize the restraint as either horizontal or vertical. When the Sealy case was briefed and argued, White Motor was the governing law at the time and held that that vertical territorial restraints were entitled to rule of reason treatment. Citing White Motor, Justice Fortas began the Sealy opinion by noting that "this Court has distinguished between horizontal and vertical territorial limitations. For purposes of the impact of the Sherman Act, it is first necessary to determine whether the territorial arrangements here are to be treated as the creature of the licensor, Sealy, or as the product of a horizontal arrangement among the licensees." "115 The Court proceeded to analyze the relationship among the licensees, which owned "substantially all" of Sealy's stock, and concluded that the "territorial arrangements must

\footnotetext{
${ }^{112}$ United States v. Sealy, 388 U.S. 350 (1967).

113388 U.S. at _ ("Sealy agreed with each licensee not to license any other person to manufacture or sell in the designated area; and the licensee agreed not to manufacture or sell 'Sealy products' outside the designated area.").

114388 U.S. at

115388 U.S. at _ (White Motor Co. v. United States, 372 U.S. 253 (1963)).
} 
be regarded as the creature of horizontal action by the licensees."116 Justice Harlan, in his dissent, argued strenuously that the restraint was properly categorized as vertical. ${ }^{117}$

The Court's categorization process seems peculiar for two reasons. First, one of the great ironies of Sealy is the timing of the decision. Sealy relied on White Motor to show the importance of categorization. Yet the same day it decided Sealy, the Court delivered its opinion in United States v. Arnold, Schwinn \& Co., ${ }^{118}$ which overruled White Motor and held vertical non-price restraints represented a new category of per se illegal agreements. Thus, as of June 12, 1967, both horizontal non-price restraints and vertical non-price restraints were per se illegal. If ever there were an unnecessary debate over categorization, this was it. The Supreme Court decided Sealy without acknowledging that Schwinn reversed White Motor and brought vertical non-price restraints within the per se rule. Indeed, the majority opinion never even mentions Schwinn.

Second, even ignoring Schwinn's impending reversal of White Motor, it is unclear how this categorization step aided the Court's ultimate decision to condemn the territorial restraints. The Court condemned Sealy's non-price restraints in large part because they were implemented in "connection with [] unlawful price-fixing." 119 Given this larger and, if proven, clearly per se illegal - conduct, the Court invested effort in categorizing

\footnotetext{
116388 U.S. at

${ }^{117}$ United States v. Sealy, 388 U.S. 350, 358 (1967) (Harlan, J., dissenting) ("I cannot agree that on this record the restrictive territorial arrangements here challenged are properly to be classified as 'horizontal,' and hence illegal per se under established antitrust doctrine. I believe that they should be regarded as 'vertical' and thus, as the Court recognizes, subject to different antitrust evaluation.")

118388 U.S. 365 (1967). Schwinn itself was overruled a decade later in Sylvania.

119388 U.S. at _ (Sealy did not appeal the district court's injunction of its vertical price-fixing).
} 
the restraint as horizontal even though it indicates it would have condemned the restraint regardless. ${ }^{120}$ In sum, much unnecessary effort is invested in needless categorization.

Sealy set the stage for the upcoming showdown between horizontal and vertical non-price restraints reflected in the Supreme Court's opinions in Topco ${ }^{121}$ and Sylvania. ${ }^{122}$ First, in Topco, a group of smaller and medium-sized regional stores created a new line of branded products in order to compete against national store brands. The cooperative sought to prevent free-riding by allocating de facto exclusive territories to the member stores. Because it viewed the relationship among the stores as horizontal, the Supreme Court condemned the territorial restraint as per se illegal. The Court rejected the argument that intrabrand competition could be sacrificed to increase interbrand competition. $^{123}$

Then, in Sylvania, the Supreme Court seemingly reversed course and held that a manufacturer could impose territorial restraints in an effort to limit free-riding even though the restraint would lessen intrabrand competition in an effort to increase interbrand competition. The precise argument that the Court forbade in Topco, it endorsed in Sylvania. While this may seem like a reasonable evolution in antitrust doctrine, the Court did not actually reverse Topco; instead, it reaffirmed Topco while limiting its per se rule to horizontal restraints. The Sylvania Court predicted that " $[\mathrm{t}]$ here may be occasional problems in differentiating vertical restrictions from horizontal

\footnotetext{
${ }^{120} 388$ U.S. at _ ("For here, the arrangements for territorial limitations are part of 'an aggregation of trade restraints' including unlawful price-fixing and policing. Within settled doctrine, they are unlawful under $\S 1$ of the Sherman Act without the necessity for an inquiry in each particular case as to their business or economic justification, their impact in the marketplace, or their reasonableness.")

${ }^{121}$ United States v. Topco Associates, Inc., 405 U.S. 596 (1972).

122 Continental T. V., Inc. v. GTE Sylvania Inc., 433 U.S. 36 (1977).

${ }^{123} 405$ U.S. at 612.
} 
restrictions originating in agreements among the retailers. There is no doubt that restrictions in the latter category would be illegal per se..."124 The Court distinguished Sylvania because the agreement there was vertical in nature.

In the aftermath of Topco and Sylvania, how courts conceive of the relationship will determine liability for cooperatives. Categorization becomes dispositive. Any given restraint has the same competitive effects regardless of how courts categorize it. Yet, if it is characterized as vertical, it will probably survive a rule of reason analysis; conversely, if it is characterized as horizontal, it will be condemned as per se illegal. This means that litigants and judges focus on the characterization of a challenged restraint as either horizontal or vertical, instead of on the actual or predicted anticompetitive effects.

We don't mean to suggest that there is nothing to the horizontal-vertical distinction. For example, horizontal cooperative branding activity may be more likely to be used as a cover for a cartel among preexisting market participants. But the Court has turned an occasional difference in how the rule of reason would treat two otherwisesimilar restraints into a bright-line rule that makes the differences between those restraints the critical inquiry.

\section{b. Dual Distribution}

The horizontal versus vertical debate also pervades antitrust litigation involving dual distributors. Dual distribution exists when a manufacturer uses independent firms to distribute its product to some customers, while supplying other customers directly. A manufacturer may pursue a dual distribution strategy for several reasons. A manufacturer may have the capacity to distribute some but not all of its product. It may "desire to

${ }^{124}$ Continental T. V., Inc. v. GTE Sylvania Inc., 433 U.S. 36, 58 n.28 (1977) (citing Topco). 
protect its reputation, by preventing distributors from engaging in opportunistic behavior. Dual distribution also permits manufacturers to more easily monitor their distribution systems and to provide competitive stimulus to independent distributors." ${ }^{\prime 25}$ While there are strong efficiency arguments for dual distribution, some observers fear that such scheme can be used "to facilitate price squeezes on independent dealers and to implement price discrimination." 126

Dual distribution does not in and of itself violate antitrust law. ${ }^{127}$ It would be absurd for antitrust law to command that a manufacturer who uses independent vendors to supply some of its customers must use independent vendors to supply all of its customers. Nevertheless, dual distribution systems can raise antitrust concerns when the manufacturer possesses market power and employs the dual distribution framework to squelch competition in the downstream market. ${ }^{128}$ When a dual distributor imposes nonprice restraints, such as assigning exclusive territories, this creates an issue over how to characterize the restraint.

While the traditional manufacturer-distributor relationship is clearly vertical, once the manufacturer enters the same level of the supply chain as its distributors, their relationship contains a horizontal element. As a result, "the same territorial or customer

\footnotetext{
${ }^{125}$ Robert Zwirb, Dual Distribution and Antitrust Law, 21 LOY. L.A.L. REV. 1273, 1274 n.2. (1988)

${ }^{126}$ Id. (citing Schwartz \& Eisenstadt, Vertical Restraints, U.S. Dept. of Justice Antitrust Div., Econ. Policy Office Discussion Paper, at 65-71 (Dec. 2, 1982)).

127 See Dart Industries v. Plunkett Co., 704 F.2d 496, 499 (10th Cir. 1983) ("selling directly to certain large accounts reflects a dual distribution system that standing alone, is perfectly lawful.”); In Rea v. Ford Motor Co., 355 F. Supp. 842, 864 (W.D. Pa. 1973) ("We have no doubt that there is nothing inherently evil in a dual distribution system whereby a manufacturer may sell its own products to the customers directly through company outlets along side sic independent dealers.").

${ }^{128}$ See Rea, 355 F. Supp. at 867 ("Whether dual distribution is or is not illegal or evil in and of itself, it does become an antitrust problem in the context of its use by a company possessing substantial market power.")
} 
restrictions that were previously viewed as vertical may be reclassified as market allocations among competitors, or horizontal restraints of trade...",129

Some courts addressing the legality of dual distribution under antitrust laws have focused on categorizing the restraints as horizontal or vertical, instead of any anticompetitive effects of the challenged restraints. ${ }^{130}$ This is the natural result of Sylvania, which brought vertical non-price restraints within the rule of reason, while maintaining per se illegality for horizontal non-price restraints:

Sylvania, in effect, requires courts in dual distribution cases to characterize the restrictions at issue as either vertical or horizontal. At the same time, Sylvania emphasizes that the determination of legality of distributional restraints 'must be based upon demonstrable economic effect rather than ... upon formalistic line drawing.' While Sylvania requires courts to rely upon economic analysis in deciding distribution issues, its distinction between 'vertical' and 'horizontal' restraints forces courts to engage in the very 'formalistic line drawing' it purports to be eschewing. ${ }^{131}$

Once the categorization becomes dispositive, litigants and judges spend their debating the category, not the economic effects of the challenged restraint. ${ }^{132}$

\footnotetext{
${ }^{129}$ Zwirb, supra note xx at 1276 (citing Altschuler, Sylvania, Vertical Restraints, and Dual Distribution, 25 ANTITRUST BULL. 1, 2 (1980); Baker, Interconnected Problems of Doctrine and Economics in the section one Labyrinth: Is Sylvania A Way Out?, 67 VA. L. REV. 1457, 1509-15 (1981); Liebeler, Intrabrand 'Cartels' Under GTE Sylvania, 30 UCLA L. REV. 1, 49-50 (1982)).

${ }^{130}$ See Brett \& Wallace supra note $\mathrm{xx}$ at 1000.

${ }^{131}$ Zwirb, supra note xx at 1284 (quoting Sylvania, 433 U.S. at 59).

${ }^{132}$ See Zwirb, supra note xx at 1298 ("in cases decided after Sylvania, the legality of [dual distribution] restraints turned upon a determination of whether they were 'vertical' or "horizontal."'); id at 1319 ("By concentrating on the form of the distribution arrangement involved, most decisions fail to evaluate distribution restraints on the basis of economic effect.").
} 
The vertical-horizontal characterization remains unsettled as scholars debate whether dual distributorships are horizontal or vertical. ${ }^{133}$ Most courts conclude that dual distribution schemes are essentially vertical. ${ }^{134}$ However, some courts, albeit a minority of them, have treated dual distribution systems as horizontal and, consequently, per se illegal. ${ }^{135}$ And "[a] number of lower courts have held ... that the presence of dual distribution transforms intrabrand restrictions otherwise vertical in origin into horizontal ones."136

Courts routinely engage in a laborious process of categorizing the dual distribution schemes as either horizontal or vertical. Some judges focus on the source of the particular restraint within a dual distribution network, ${ }^{137}$ asking whether the manufacturer-defendant "was acting as a supplier (in a vertical capacity) or as a competitor distributor (in a horizontal capacity) when it allegedly [imposed a]

${ }^{133}$ Zwirb, supra note xx at 1286 (discussing Schwartz \& Eisenstadt, at 73-74).

${ }^{134}$ See, e.g., Smalley \& Co. v. Emerson \& Cuming, Inc., 13 F.3d 366, 368 (10th Cir. 1993); Tunis Bros. Co. v. Ford Motor Co., 763 F.2d 1482 (3d Cir. 1985); Midwestern Waffles, Inc. v. Waffle House, Inc., 734 F.2d 705 (11th Cir. 1984); Graphic Prods. v. Itek Corp., 717 F.2d 1560 (11th Cir. 1983); Dart Indus. v. Plunkett Co. of Okla., 704 F.2d 496 (10th Cir. 1983); Davis-Watkins Co. v. Service Merchandise, 686 F.2d 1190 (6th Cir. 1982); Krehl v. Baskin-Robbins Ice Cream Co., 664 F.2d 1348 (9th Cir. 1982); Donald B. Rice Tire Co. v. Michelin Tire Corp., 638 F.2d 15 (4th Cir. 1981); Copy-Data Sys., Inc. v. Toshiba Am., Inc., 663 F.2d 405 (2d Cir. 1981); Red Diamond Supply, Inc. v. Liquid Carbonic Corp., 637 F.2d 1001 (5th Cir. 1981); Abadir \& Co. v. First Miss. Corp., 651 F.2d 422 (5th Cir. 1981)); H\&B Equip. Co. v. International Harvester Co., 577 F.2d 239 (5th Cir. 1978); Martin B. Glauser Dodge Co. v. Chrysler Corp., 570 F.2d 72 (3d Cir. 1977).

${ }^{135}$ See, e.g., Dougherty v. Continental Oil Co., 579 F.2d 954 (5th Cir. 1978), appeal dismissed per stipulation, 591 F.2d 1206 (5th Cir. 1979); see also Guild Wineries \& Distilleries v. J.

Sosnick \& Son, 162 Cal. Rptr. 87, 91 (1980) ("It is settled that distributors cannot lawfully agree to divide territories or customers."); Casey, supra note xx at 438-439 (citing Pitchford v. PEPI, Inc., 531 F.2d 92 (3d Cir. 1975), cert. denied, 426 U.S. 935 (1976), rem'd as to damages, 435 F. Supp. 685 (W.D. Pa. 1977), aff'd, 582 F.2d 1275 (3d Cir. 1978), cert. denied, 440 U.S. 981 (1979); Krehl v. Baskin-Robbins Ice Cream Co., 78 F.R.D. 108 (C.D. Cal. 1978)); see also Brett \& Wallace supra note xx at 992 ("Despite the fact that in none of the Pitchford opinions was it explicitly so stated, one is left with the conclusion that, at least in the Third Circuit, dual distribution restraints are illegal per se.”).

${ }^{136}$ Krehl, 1979-2 Trade Cas. at 78,704.

${ }^{137}$ See, e.g., Red Diamond Supply, Inc. v. Liquid Carbonic Corp., 637 F.2d 1001, 1002-04 (5th Cir. 1981); Donald B. Rice Tire Co. v. Michelin Tire Corp., 638 F.2d 15, 16-17 (1981). 
territory[ial] restraint." ${ }^{\prime 138}$ Because a dual distribution scheme contains both horizontal and vertical aspects, courts then invest their energies into determining which of these aspects "predominates." ${ }^{\prime 139}$ Courts then use the source of a particular restraint to determine which aspect predominates, reasoning that "[c]onspiracies between a manufacturer and its distributors are only treated as horizontal, however, when the source of the conspiracy is a combination of the distributors. [But when] ... the asserted originator of the plan [is] the manufacturer, ... antitrust law treats the conspiracy as a vertical restraint, and those restrictions are now judged under the rule of reason." 140

Under this approach, the source of the restraint can be outcome determinative: "If the restriction originates from the manufacturer, the arrangement is deemed vertical and subject to the rule of reason. But if it is initiated by dealers or distributors acting in concert with themselves or with the manufacturer, a horizontal conspiracy or cartel is presumed, and the arrangement is deemed illegal per se." ${ }^{\prime 14}$ This seems too facile. As Professor Liebeler recognized some years ago, "The statement that someone 'imposed' something is not a meaningful statement in economic terms, and, in addition, is a poor way to determine whether an arrangement is horizontal or vertical. . . A more relevant inquiry is whether an arrangement has the potential to restrict output."142 Yet although the

${ }^{138}$ L. C. Williams Oil Co. v. Exxon Corp., 625 F. Supp. 477 (M.D.N.C. 1985).

${ }^{139}$ See Zwirb, supra note xx at 1316 ("Rather than focusing on the economic impact of Exxon's distribution arrangements, the court fruitlessly attempted to determine which aspect 'predominated'--the vertical or horizontal corporate personality.").

${ }^{140}$ H\&B Equipment Co. v. International Harvester, 577 F.2d 239, 245-46 (5th Cir. 1978).

${ }^{141}$ Zwirb, supra note $\mathrm{xx}$ at 1287.

${ }^{142}$ Liebeler, Book Review, 66 CAL. L. REV. 1317, 1334 n. 41 (1978) (reviewing R. BORK, THE ANTITRUST PARADOX: A POLICY AT WAR WITH ITSELF (1978)).

This is not to say that source is irrelevant. As Herb Hovenkamp explains: "The two distinguishing features of intrabrand restraints are that they explicitly control only a particular manufacturer's own brand, and powerful dealers have an incentive to impose them, sometimes for anti-competitive purposes. So one can draw this pair of generalizations: intrabrand restraints initiated by manufacturers acting without coercion from their dealers are almost certain to be 
source inquiry does not establish a restraint's competitive effects, courts sometimes

devote significant time into determining the source of the restraint. ${ }^{143}$

The vertical-horizontal categorization process in dual distribution cases does not lead to better results. Courts invest significant resources debating whether a particular restraint within a dual distribution scheme is horizontal or vertical. ${ }^{144}$ And while the vertical-horizontal characterization is often dispositive in dual distribution cases, that inquiry says little about the actual economic effects of a given restraint within a dual distribution framework. ${ }^{145}$

Ironically, in their zeal to categorize, some courts even perform a rule of reason analysis in order to determine whether the restraint at issue is vertical and thus should be analyzed under the rule of reason! In addition to examining the source of the restraint, courts in dual distribution cases will sometimes scrutinize "the purpose and effect of the restraint in order to determine whether the restraint was horizontal or vertical." ${ }^{146}$ In several cases, courts "have examined the origin, purpose and effect of the restraint and

competitive. By contrast, restraints imposed on manufacturers by powerful dealers or dealers' groups are more likely to be anticompetitive." HOVENKAMP (“ANTITRUST ENTERPRISE"), supra note $\mathrm{xx}$ at 185 . But it is wasteful to explain the source in order to characterize the restraint before applying a rule of reason, instead of simply considering the source in order to predict the restraint's effect on output.

${ }^{143}$ See Abadir, at 427 n.5 ("Thus, vertical market-distributing agreements must truly be imposed by a supplier, in fact. Market-distributing agreements which are initiated by distributors are horizontal, even if the supplier is nominally a party to the contract.").

${ }^{144}$ See Bell \& Howell, 803 F.2d 1473 ("Although a manufacturer's relationship with its distributors has a horizontal aspect when it acts as a distributor itself, it remains primarily a vertical relationship. A manufacturer retains some right to place restraints on its distributors to improve its ability to compete in the product market.").

${ }^{145}$ Zwirb, supra note xx at 1291 ("Decisions that characterize arrangements on the basis of form or source can hardly be described as opinions based on 'economic effect."').

${ }^{146}$ Casey, supra note xx at 444 (discussing Davis-Watkins Co. v. Service Merchandise, 686 F.2d 1190, 1197 (6th Cir. 1982)). 
have then proceeded to classify it as either horizontal or vertical. ${ }^{, 147}$ For example, in one case, the Fifth Circuit reasoned that "the [dual distributor's] restraints were vertical because they resulted in a guaranteed year-round market for the product. Therefore, the court concluded that the rule of reason was the appropriate standard to evaluate the dual distributor restraints."148 The court essentially concludes that its quick rule of reason analysis suggests a procompetitive explanation for the restraint, and therefore argues that the restraint must be vertical because that characterization allows the court to apply the rule of reason. Similarly, the Ninth Circuit has "conclude[d] that, in the absence of proof of anti-competitive purpose or effect, dual distribution systems must be evaluated under the traditional rule of reason standard." ${ }^{\prime 49}$ This makes little sense; looking for proof of anticompetitive effects $i$ rule of reason analysis and finding proof of such effects essentially establishes the prima facie case under the rule of reason.

Categorization here has become the end instead of the means. It focuses attention on the wrong issue as courts look at the effects of the restraint to determine its category instead of its legality. That is exactly backwards. The reason that dual distribution schemes do not violate antitrust laws is not because they are vertical, but because they generally do not unreasonably restrain competition. Once the court has determined that

${ }^{147}$ Brett \& Wallace supra note xx at 995-96 (citing Ohio-Sealy Mattress Mfg. Co. v. Sealy, Inc., 585 F.2d 821 (7th Cir. 1978), cert. denied, 440 U.S. 930 (1979); Dougherty v. Continental Oil Co., 579 F.2d 954 (5th Cir. 1978), appeal dismissed per stipulation, 591 F.2d 1206 (5th Cir. 1979); Westpoint Pepperell, Inc. v. Rea, 1980-2 Trade Cas. 75,739 (N.D. Cal.); Krehl v. BaskinRobbins Ice Cream Co., 1979-2 Trade Cas. 78,699 (C.D. Cal.); Amway Corp., [1976-1979 Transfer Binder] TRADE REC. REP. (CCH) i 21,574 (FTC May 8, 1979); 91 F.T.C. at 517; Guild Wineries and Distilleries v. J. Sosnick 8c Son, 102 Cal. App. 3d 627, 162 Cal. Rptr. 87 (1980)).

${ }^{148}$ Casey, supra note xx at 441 (discussing Abadir \& Co. v. First Mississippi Corp.).

149 Krehl v. Baskin-Robbins Ice Cream Co., 664 F.2d 1348, 1357 (9th Cir. 1982). But note that the court also asserted that "our inquiry focuses not on whether the vertical or horizontal aspects of the system predominate, but rather, on the actual competitive impact of the dual distribution system employed..." Id. at 1356. 
the challenged restraint does not unreasonably restrain competition, the section one inquiry should end, not proceed to a categorization step that is, at best, unnecessary.

Of course, many courts do consider the effects of a challenged restraint ${ }^{150}$ and some simply hold that restraints within dual distribution schemes are analyzed under the rule of reason without regard to the vertical/horizontal classification. ${ }^{151}$ This rule of reason analysis, not an artificial categorization, is how antitrust analysis of dual distribution should be performed. ${ }^{152}$

\section{c. Group Boycotts}

The horizontal-vertical distinction also creates confusion in the application of the per se rule to group boycotts. Although the Supreme Court had initially condemned group boycotts as per se illegal, ${ }^{153}$ the Court's subsequent erosion of the per se rule has led lower courts to characterize group boycotts as either horizontal or vertical, and to reserve per se condemnation for those concerted refusals to deal where there is "concerted activity between two or more horizontal competitors." ${ }^{154}$ Conversely, "[t]he

\footnotetext{
${ }^{150}$ See Red Diamond at 1004-05 ("That Liquid also distributed some of its own goods does not alter the situation. When a producer elects to market its goods through distributors, the latter are not, in an economic sense, competitors of the producer even though the producer also markets some of its goods itself."); see also See Zwirb, supra note xx at 1309 ("Red Diamond is thus distinctive for integrating economic insights into a formalistic framework.").

${ }^{151}$ Jack Walters \& Sons Corp. v. Morton Bldgs., Inc., 1983-1 Trade Cas. (CCH) $₫$ 65,284, at 69,668 (E.D. Wis. 1983), aff'd, 737 F.2d 698 (7th Cir. 1984) ("The better-reasoned decisions have held that a rule of reason analysis is applicable in dual distribution systems."); see also Zwirb, supra note xx at 1313 ("Instead of becoming immersed in a classification controversy, the Sixth Circuit simply stated that dual distributor restrictions are analyzed by the rule of reason.") (discussing Davis-Watkins Co. v. Service Merchandise, 686 F.2d 1190 (6th Cir. 1982)).

${ }^{152}$ See infra notes _ to _ and accompanying text.

${ }^{153}$ Klor's, Inc. v. Broadway-Hale Stores, Inc., 359 U.S. 207 (1959). For a discussion of the history, see supra notes ___ and accompanying text.

${ }^{154}$ Cascade Cabinet Co. v. Western Cabinet \& Millwork, 710 F.2d 1366, 1370 (9th Cir.1983); Brookins v. Intl Motor Contest Ass'n, 219 F.3d 849, 854 (8th Cir. 2000) (“'[P]recedent limits the
} 
per se rule is never applied automatically when the concerted refusal to deal is vertical, rather than horizontal."155 This raises the issue of what makes a boycott "horizontal." Some courts hold that the challenged "boycott must originate among the horizontal competitors," $" 156$ just as courts have held in the dual distribution context. Others say merely that " $[\mathrm{s}]$ ome horizontal concert of action must be taken against the victims of the restraint in order for the per se rule to apply."157

Importing the horizontal versus vertical dichotomy into boycott jurisprudence is particularly cumbersome - even more so than with territorial restraints - because boycotts often involve multiple relationships. For example, in Klor's, the ringleader of the alleged conspiracy (Broadway Hale) was a competitor of the plaintiff, but was not in a horizontal relationship with any of the other conspirators, none of whom were rivals of the plaintiff. ${ }^{158}$ Despite this, some lower courts focus on the "obvious horizontal character to the conspiracy" in Klor's. ${ }^{159}$ Yet, under the reasoning of Sealy, the concerted refusal to deal would seem to be vertically driven. Broadway-Hale was neither controlled by nor competing against any other member of the conspiracy. At the end of the day, we are left with courts investing their time considering whether a particular group boycott is horizontal, instead of whether it is having anticompetitive effects. ${ }^{160}$

per se rule in the boycott context to cases involving horizontal agreements among direct competitors." (quoting Nynex Corp. v. Discon, Inc., 525 U.S. 128, 135 (1998))).

155 Tominaga v. Shepard, 682 F.Supp. 1489, 1495 (C.D. Cal. 1988) (citation omitted).

${ }^{156}$ Flash Elec., Inc. v. Universal Music \& Video Dist. Corp., 312 F.Supp.2d 379, 388 n.4 (E.D.N.Y. 2004).

${ }^{157}$ Tominaga v. Shepard, 682 F.Supp. 1489, 1495 (C.D. Cal. 1988) (citing Gough v. Rossmoor Corp., 585 F.2d 381, 387 (9th Cir.1978)).

${ }^{158}$ Klor's, Inc. v. Broadway-Hale Stores, Inc., 359 U.S. 207 (1959).

${ }^{159}$ Lomar Wholesale Grocery, Inc. v. Dieter's Gourmet Foods, Inc., 824 F.2d 582, 590-91 (8th Cir. 1987).

${ }^{160}$ See Rossi, 156 F.3d at 462. 


\section{d. Summary}

The disparate treatment between vertical and horizontal restraints is theoretically a function of their different economic effects. The Court reiterated this year in Leegin that its "recent cases formulate antitrust principles in accordance with the appreciated differences in economic effect between vertical and horizontal agreements..." $" 161$ Thus, according to the Court, restraints denominated as vertical should receive more deferential treatment than those adjudged to be horizontal. ${ }^{162}$ While such an approach is defensible as a theoretical matter, the practical effect has been to convert antitrust litigation into a laborious process of characterization and mischaracterization in which the actual economic effects of the challenged restraint play a minor role in the antitrust analysis. The differences between vertical and horizontal conduct can sometimes be significant, but they are not the beginning and the end of the inquiry. Making them so simply leads to fights over which box should hold conduct that often doesn't easily fit into any box.

\section{Voluntary versus Coerced.}

The distinction between voluntary and coerced patent licenses we identified above $^{163}$ is naturally manipulable. While in the abstract there may be some transactions that are clearly voluntary and others that are coerced, in some sense all contracts could be characterized as either voluntary (the licensee did after all agree to the terms) or coerced

\footnotetext{
${ }^{161}$ Leegin Creative Leather Products, Inc. v. PSKS, Inc., 127 S.Ct. 2705 (2007).

${ }^{162}$ See Leegin Creative Leather Products, Inc. v. PSKS, Inc., 127 S.Ct. 2705 (2007) ("In later cases, however, the Court rejected the approach of reliance on rules governing horizontal restraints when defining rules applicable to vertical ones. See, e.g., Business Electronics, supra, at 734, 108 S.Ct. 1515 (disclaiming the "notion of equivalence between the scope of horizontal per se illegality and that of vertical per se illegality"); Maricopa County, supra, at 348, n. 18, 102 S.Ct. 2466 (noting that "horizontal restraints are generally less defensible than vertical restraints").").

163 See supra notes ____ and accompanying text.
} 
(licensors presumably extracted as much value as they could from the licensees, and they would not have needed the license were it not for at least an implicit threat of patent suit). Further, even if there is a theoretical distinction we might want to maintain, as a practical matter the question of coercion will be effectively impossible to prove in court. The parties might reasonably be expected to contradict each other in testifying on the issue, either because one is lying or because they have different perspectives on voluntariness. Nor will a contract recital of voluntariness tell us much about the actual state of affairs, since someone coerced into signing a license presumably can be coerced into signing one that recites that it is voluntary. The ability of licensees to acquire individual rather than group patent licenses may bear on voluntariness, though cases such as this often involve package licenses offered at a discount off of the collective price of individual licenses.

Something similar is likely in the copyright block booking cases. Even if we could determine in extreme cases whether a package license of copyrighted works was voluntary or not, we will face intermediate cases in which copyright owners offer package discounts. Unless we are willing to ban all package discounts of informationbased goods - something antitrust law is clearly unwilling to do in other areas - the "voluntary vs. coerced" distinction will be subject to characterization problems.

It is true that there are some limited circumstances in which coerced package licensing or block booking may have negative consequences that voluntary deals would not. Licensees dealing with a patent pool, for instance, will likely be willing to take licenses to patents essential to the technology but would not voluntarily agree to take licenses to other patents that are competitive with rather than complementary to their own 
products. ${ }^{164}$ But the fact that there is something to the distinction in theory doesn't mean that it will work in practice. Licensors who want to coerce agreement to package terms will try to manipulate the transaction to make it appear voluntary, and licensees will often have the opposite incentive. The result is the creation of boxes that map imperfectly, if at all, to actual economic effects. Here, too, we would be better off inquiring into those economic effects than into whether the conduct fits into an artificial category the law has created.

\section{Unilateral v. Concerted Conduct}

The distinction between unilateral and concerted action is fundamental because it serves to distinguish section 1 from section 2 of the Sherman Act. This is important because section 2 does not treat any unilateral conduct as per se illegal. And if two competitors merge into one company, we apply an alternative rule, derived from section 7 of the Clayton Act: whether the merger is likely to substantially lessen competition or lead to a monopoly. ${ }^{165}$

The fundamental distinction between unilateral and concerted conduct makes a good deal of sense as a matter of antitrust policy. Unilateral acts have the potential for productive efficiencies generally lacking in agreements between competitors. They are also much harder to police, since companies have to make pricing and output decisions, while they don't have to agree with competitors. For both reasons, the administrative and

164 In its most recent treatment of the issue, the Federal Circuit rejected the essentiality criterion in evaluating patent pools. U.S. International Trade Comm'n v. Philips, 424 F.3d 1179 (Fed. Cir. 2005). This was a mistake. Limiting a pool to essential patents serves the useful purpose of permitting competition where it is possible. But just because we believe the essential-nonessential patent distinction is important doesn't mean it, or any other category, should necessarily be determinative.

16515 U.S.C. $\S 18$. 
error costs are much greater when policing unilateral acts than when policing agreements.

Accordingly, the law treats agreements, especially among competitors, much more harshly than unilateral conduct.

The fact that this distinction makes sense does not prevent it from being manipulated, however. Companies aware of the distinction naturally seek to characterize their conduct as unilateral rather than concerted. This has led to difficult evidentiary questions where defendants act in parallel, but deny that they have acted in concert. ${ }^{166}$ It has also led to the creation of boxes in which we assume without detailed investigation that concerted action either does or does not exist. Four examples follow.

\section{a. Is it a Joint Venture? Collaborations Among Competitors}

Joint ventures blur the sharp division between unilateral and concerted action. Is a joint venture between competitors simply an agreement between independent entities, subject to section 1 of the Sherman Act? Or is it effectively the creation of a new merged entity subject to section 7 of the Clayton Act? Courts have taken both positions. ${ }^{167}$ And whichever position courts take, they then must face the separate problem of whether and how to police the dealings between the joint venture and its parents. That relationship could be characterized either as dealing among competitors (subject to section 1) or as dealings within a corporate entity (subject to Copperweld and therefore virtually immune

166 See Champagne Metals v. Ken-Mac Metals, Inc., 458 F.3d 1073 (10 ${ }^{\text {th }}$ Cir. 2006) (reversing district court determination that concerted conduct could not be proven); William H. Page, Communication and Concerted Action, 38 Loy. U. Chi. L. Rev. 405 (2007) (discussing these difficulties, and proposing that plaintiffs must prove that the defendants have actually communicated with each other).

167 Compare Northrop Corp. v. McDonnell Douglas Corp., 705 F.2d 1030 (9 ${ }^{\text {th }}$ Cir. 1983) (evaluating joint venture under section 1) with United States v. Penn-Olin Corp., 378 U.S. 158 (1964) (evaluating joint venture under section 7 of the Clayton Act). Cf. FTC Competitor Collaboration Guidelines (1998) (evaluating both approaches). 
from scrutiny). ${ }^{168}$ Characterization of the joint venture can determine the legality of both the venture itself and its agreements with others. This problem of characterization was central to the Supreme Court's recent Dagher case. The Ninth Circuit had held that two oil companies that formed a joint venture, ending competition between them and jointly refining and marketing gasoline, violated section 1 when they agreed to set the price for the oil produced by the joint venture. ${ }^{169}$ The Supreme Court reversed, holding that a joint venture did not engage in price fixing when it set the prices at which its members would sell through the venture. ${ }^{170}$ The difference was entirely one of characterization: are two companies that forego competition by entering into a joint venture nonetheless two companies agreeing on price, or is the joint venture a single entity making its own pricing decision?

The irony of this characterization debate to an economist is that it arguably shouldn't matter at all. Transactions costs economics thinks of a firm as a collection of actors organized into a group because it is more efficient to do so than to deal with each other through outside contracts. ${ }^{171} \mathrm{~A}$ change in the legal rules that affects outside transactions differently than integration into a firm should merely prompt integration or disintegration, not a change in the actual behavior of the actors. ${ }^{172}$ This doesn't mean

\footnotetext{
168 Guidelines, supra note _, at _..

169 Dagher v. Saudi Refining, Inc., 369 F.3d 1108, 1116 (9 $9^{\text {th }}$ Cir. 2004).

170 Texaco, Inc. v. Dagher, 126 S.Ct. 1276, 1279 (2006).

171 The founding father of transactions costs economics is Oliver Williamson. See, e.g., See Oliver E. Williamson, The Mechanisms of Governance 233-34 (Oxford 1996); Oliver E. Williamson, The Economic Institutions of Capitalism 30 (Collier Macmillan 1985). TCE is itself an offshoot of the Ronald Coase's theory of the firm. See Ronald H. Coase, The Nature of the Firm, 4 Economica 386 (1937), reprinted in Ronald H. Coase, The Firm, the Market, and the Law 33 (Chicago 1988). For a flavor of the more general literature on the theory of the firm and how law affects firm structure, see generally Jason Scott Johnston, The Influence of The Nature of the Firm on the Theory of Corporate Law, 18 J. Corp. L. 213 (1993).

172 For an example, see, e.g., Dan L. Burk \& Brett McDonnell, The Goldilocks Hypothesis: Balancing Intellectual Property Rights at the Boundary of the Firm, 2007 U. Ill. L. Rev. 575.
} 
antitrust should never treat outside firms differently than inside divisions, of course, but it does suggest that if we can't agree whether to characterize a cooperative or joint venture as a single entity or as a group of autonomous would-be competitors, it may not be worth wasting a lot of time trying to precisely delineate this boundary. In an ideal world, we would analyze the economic effect of the venture without regard to how it is characterized. $^{173}$

\section{b. Dealer Terminations}

The second example involves dealer termination cases. The courts had established in a series of cases involving termination of dealers by distributors that a distributor cannot agree with one dealer to terminate another dealer; to do so is illegal per se. ${ }^{174}$ The worry is that dealers have an incentive to eliminate price-cutting competitors, and if they can collectively pressure the distributor to terminate the price-cutter, they can enforce higher retail prices. ${ }^{175}$ Nor can distributors agree with the price-cutting dealer to stop discounting, because doing so is a concerted agreement to set minimum resale prices, and

173 The FTC took a significant step towards letting the economic effects rather than the form of the venture determine the outcome in its Competitor Collaboration Guidelines. Guidelines, supra note _, at _. But courts have yet to take the same approach.

To be fair, the result of the Dagher case is not expressly to insulate joint venture pricing from review, but rather to apply the rule of reason. We think the rule of reason may well be the right test here. But the references to the joint venture as a single entity making a unilateral pricing decision suggests that the Copperweld rule of virtually per se legality may end up applying to such arrangements.

174 See, e.g., Cernuto,Inc. v. United Cabinet Corp., 595 F.2d 164 (3d Cir .1979); Bostick Oil Co. v. Michelin Tire Corp., 702 F.2d 1207, $1213-15$ (4 ${ }^{\text {th }}$ Cir. 1983). This rule survived Monsanto $v$. Spray-Rite Serv. Corp., 465 U.S. 752, 768 (1984); that decision set a high pleading standard for proof of agreement, but maintained the rule that such agreement, if proven, is illegal per se.

175 Whether this concern actually makes sense is open to question, but that's not directly relevant to our point in this section. 
therefore was also illegal per se until 2007, and is now judged under the rule of reason. ${ }^{176}$ In Monsanto v. Spray-Rite, ${ }^{177}$ however, the Court held that a distributor who could not agree with its dealer was nonetheless free to unilaterally announce a set of rules with which all dealers must comply and to terminate dealers who fail to do so. Further, it set a high standard of proof for agreement in such a case, requiring evidence of "a conscious commitment to a common scheme designed to achieve an unlawful objective."178 In a case such as this, the line between a dealer-distributor agreement and a unilateral restriction starts to blur. Agree with dealers on a policy and your conduct is illegal per se. Announce the identical policy yourself, even if everyone knows that you are responding to pressure from dealers, and it's not. ${ }^{179}$ That distinction makes little sense. ${ }^{180}$

The Court's decision four years later in Business Electronics v. Sharp Electronics added a new dimension to this artificial distinction. ${ }^{181}$ That case held that agreements to terminate a price cutter are only per se illegal if there is also an "agreement on price levels." "182 It therefore took the per se illegal box created by Monsanto - agreements to terminate dealers - and further carved it into two sub-boxes, one for agreements that specifically set a price and another for agreements that don't. This distinction makes even less sense than Monsanto's. Termination of price cutters will serve to stabilize a

176 Colgate \& Co. v. United States, 250 U.S. 300 (1919) (per se rule); Leegin Creative Leather Prods. v. PSKS, 127 S.Ct. 2705 (2007).

177 Monsanto, 465 U.S. at 752.

178 Id. at 768 .

179 For a discussion of the evidentiary problems in drawing this line, see Herbert Hovenkamp, Federal Antitrust Policy: The Law of Competition and Its Practice 468 ( $3 \mathrm{~d}$ ed. 2005).

180 See also Alan J. Meese, Intrabrand Restraints and the Theory of the Firm, 83 N.C. L. Rev. 5, 73-78 (2004). Meese goes on to argue that this justifies per se legality for all vertical conduct. Id. at 78-80. We disagree. Conduct that is sometimes anticompetitive and sometimes legitimate should not be per se illegal, but neither should it be per se legal.

181485 U.S. 717 (1988).

182 Id. at 728 . 
horizontal cartel among manufacturers even without an explicit agreement on price between each manufacturer and distributor. And after Business Electronics, manufacturers and distributors can agree to terminate any particular price cutter - and even agree to terminate them expressly because they cut prices - so long as they don't actually agree on what price level is too low. Perhaps Business Electronics really wanted to eliminate the per se rule entirely from vertical cases - the Court took a big step in that direction this Term ${ }^{183}$ - but there is no logic to the line they in fact ended up drawing.

\section{c. Conditional Refusals to Deal}

A final, related example involves a series of efforts by the makers of durable goods to capture a previously competitive aftermarket for parts and service for their goods. In a series of cases involving the makers of photocopiers and computer systems, courts faced restrictions imposed by the antitrust defendant on the use of independent service organizations. ${ }^{184}$ These restrictions often took the form of rules that refused to provide spare parts to ISOs or to customers who used ISOs. Plaintiffs characterized this as a tying arrangement, something that the law treats as concerted action. Defendants responded by arguing that their policy was unilateral and did not require agreement with the customers. In fact, the answer is somewhere in between - the rule imposed by the

183 Leegin Creative Leather Prods. v. PSKS, 127 S.Ct. 2705 (2007). Some have argued that vertical restraints of this sort can never be anticompetitive. See Easterbrook, Limits of Antitrust, supra note _, at _; Bork, Antitrust Paradox, supra note _, at _. But as Judge Richard Posner has explained, such conduct can in some circumstances be anticompetitive. Richard A. Posner, Vertical Restraints and Antitrust Policy, 72 U. Chi. L. Rev. 229 (2005); Richard A. Posner, Vertical Restrictions and "Fragile" Monopoly, 50 Antitrust Bull. 499, 500-503 (2005) (discussing Standard Fashions exclusive dealing example).

${ }_{184}$ In re Independent Serv. Orgs. Antitrust Litig., 203 F.3d 1322 (Fed. Cir. 2000); Data General v. Grumman Sys. Support, 36 F.3d 1147 ( $1^{\text {st }}$ Cir. 1994); Image Tech. Servs. v. Eastman Kodak, 125 F.3d 1195 ( $9^{\text {th }}$ Cir. 1997). 
durable goods manufacturer is not really an agreement, ${ }^{185}$ but neither is it truly a unilateral refusal to deal. Rather, it is a conditional refusal to deal, a hybrid that - like the conditional rules in Monsanto -- is neither truly unilateral nor truly concerted. ${ }^{186}$ An antitrust rule that creates a sharp division between unilateral and concerted conduct has difficulty dealing with intermediate cases such as conditional refusals to deal.

\section{d. Who Is a Single Actor?}

A final oddity presented by the sharp distinction between unilateral and concerted conduct involves determining what constitutes a single entity. In Copperweld Corp. $v$. Independence Tube ${ }^{187}$ the Court held - quite sensibly - that a corporation could not conspire with itself. In that case, the defendants were a parent corporation and its wholly owned subsidiary. The Court determined that they had "a complete unity of interest," and so should not be treated as conspirators for antitrust purposes. This makes sense; a parent and its wholly-owned subsidiary were unlikely to compete with each other in the absence of an agreement. In fact, it makes sufficient sense that an outsider might wonder that the case was brought at all. The reason has to do with the distinction between unilateral and concerted conduct. Because agreements are treated more harshly than unilateral conduct, there is a strong incentive for antitrust plaintiffs to find a conspiracy somewhere in order to take advantage of a more advantageous legal rule.

Copperweld closes the door on efforts to game that particular box, but it opens another. What if the parent company holds less than complete ownership in another

\footnotetext{
${ }^{185}$ See Christopher R. Leslie, Unilaterally Imposed Tying Arrangements and Antitrust's Concerted Action Requirement, 60 OHIO ST.L.J. 1773 (1999).

186 For elaboration, see 1 Herbert Hovenkamp et al., IP \& Antitrust $\S 13.4 b$.

187467 U.S. 752 (1984).
} 
company? If it owns a majority share in and exercises control over that company,

Copperweld should still apply, but if only one of those things is true, the case for treating the two as a single economic entity gets weaker. And we can push the line even further; the Seventh Circuit has held that the National Basketball Association is a single entity, not a collection of different teams, for antitrust purposes, even though the teams are separately owned and retain control over most of their decisions. ${ }^{188}$ Chicago Professional Sports shows that it is just as easy for defendants as plaintiffs to game the unilateral-concerted divide. $^{189}$

\section{Categories That Lie}

The point of putting particular types of conduct into the per se and rule of reason boxes is to identify a set of cases that can be resolved without a detailed inquiry into the facts or the competitive effects of each individual practice. In at least one important set of cases, however - tying arrangements - federal courts call a practice per se illegal without in fact treating it as per se illegal. ${ }^{190}$ Tying arrangements are listed as a per se category in hundreds of antitrust cases. But unlike other categories of trade restraints treated as per se illegal, the per se test as applied to tying arrangements requires the plaintiff to prove four elements: "(1) the tying and tied goods are two separate products; (2) the defendant has market power in the tying product market; (3) the defendant affords consumers no

188 Chicago Prof. Sports Ltd. v. NBA, 95 F.3d 593, 597 ( $7^{\text {th }}$ Cir. 1996).

189 For a discussion of the complexities of determining whether entities in a corporate relationship are one actor or two, see, e.g., Dean V. Williamson, Organization, Control and the Single Entity Defense in Antitrust, available at http://law.bepress.com/cgi/viewcontent.cgi?article=2200\&context=alea (working paper April 2007).

190 As we noted supra notes ___ and accompanying text, group boycotts may also be an example of a category that lies, depending on how one interprets the group boycott cases. 
choice but to purchase the tied product from it; and (4) the tying arrangement forecloses a substantial volume of commerce."191

This test for per se illegality is not truly a per se test. As one of the authors has explained "tying arrangements are really only nominally per se illegal. The per se rule against tie-ins is nominal because: (1) it requires the plaintiff to prove that the defendant has market power over the tying product, (2) it requires the plaintiff to demonstrate that a not insubstantial dollar volume of commerce in the tied product market is affected, and (3) it permits the defendant to argue that she has a legitimate business justification for imposing a tie-in. ... None of these conditions is present in a true per se scenario." ${ }^{\prime 192}$ The traditional per se test requires no showing of market power, ${ }^{193}$ and defendants whose conduct falls in other per se categories are not able to argue that business rationales validate their conduct, but tying defendants can. ${ }^{194}$

Despite the fact that under the clear language of the so-called per se test for tying, tie-ins are not, in fact, per se illegal, the Court refuses to alter the categorical label. Although writing for a four-Justice concurrence in Jefferson Parish, Justice O'Connor argued that " $[\mathrm{t}]$ he time has ...come to abandon the "per se' label" applied to tie-ins, ${ }^{195} \mathrm{a}$

${ }^{191}$ U.S. v. Microsoft Corp., 253 F.3d 34, 85 (D.C. Cir. 2001) (citing Eastman Kodak Co. v. Image Tech. Servs., Inc., 504 U.S. 451, 461-62 (1992); Jefferson Parish Hosp. Dist. No. 2 v. Hyde, 466 U.S. 2, 12-18 (1984)). If the plaintiff cannot establish these four elements, she can still argue that the tie-in violates the rule of reason.

${ }^{192}$ Christopher R. Leslie, Cutting Through Tying Theory with Occam's Razor: A Simple Explanation of Tying Arrangements, 78 TULANE LAW REVIEW 727, 735 (2004).

${ }^{193}$ Addamax Corp. v. Open Software Found., Inc., 152 F.3d 48, 51 (1st Cir. 1998) ("Where a plaintiff proves conduct that falls within a per se category, nothing more is needed for liability; the defendants' power, illicit purpose and anticompetitive effect are all said to be irrelevant.") (citing United States v. Socony-Vacuum Oil Co., 310 U.S. 150, 60 S.Ct. 811, 84 L.Ed. 1129 (1940)).

${ }^{194}$ Mozart Co. v. Mercedes-Benz of North American, Inc., 833 F.2d 1342 (9th Cir. 1987)

("Technically, there is no 'violation' of the Sherman Act if the defendant prevails on a business justification defense.”).

${ }^{195} 466$ U.S. at 35. 
majority of the Court asserted that "[i]t is far too late in the history of our antitrust jurisprudence to question the proposition that certain tying arrangements pose an unacceptable risk of stifling competition and therefore are unreasonable 'per se." "196 So the Court maintained the per se label, but added rule of reason elements to the so-called per se test for tying. ${ }^{197}$

While it may seem of no moment whether tie-ins are called per se illegal so long as they are evaluated under their own modified rule of reason, the miscategorization of tying arrangements has consequences. Although the Jefferson Parish majority claimed that it cared about "competitive consequences," not labels, ${ }^{198}$ categories matter in antitrust. Once the per se label is attached to conduct, antitrust liability attaches without proof of anti-competitive effects. Courts across most circuits have held that once the per se elements of a tying claim are established, "tying arrangements are illegal in and of themselves, without any requirement that the plaintiff make a showing of unreasonable competitive effect."199 The ill-placed per se label used in tying jurisprudence requires the court to define product markets, examine market power, and consider business justifications, yet not to examine the one factor that matters most: whether the tie-ins

\footnotetext{
${ }^{196}$ Jefferson Parish, 466 U.S. 2, 9 (1984).

${ }^{197}$ See Mozart Co. v. Mercedes-Benz of North America, 833 F.2d 1342, 1345 (9th Cir.1987) (The Jefferson Parish Court "rather than abandoning the per se rule against tying, chose to limit antitrust liability for tie-ins by insisting on a showing of actual market power in the tying product.").

${ }^{198}$ Jefferson Parish Hosp. Dist. No. 2 v. Hyde, 466 U.S. 2, 21 n.34 (1984) (“The legality of petitioners' conduct depends on its competitive consequences, not whether it can be labeled "tying." If the competitive consequences of this arrangement are not those to which the per se rule is addressed, then it should not be condemned irrespective of its label.").

${ }^{199}$ Foremost Pro Color, Inc. v. Eastman Kodak Co., 703 F.2d 534, 540-41(9th Cir. 1983) (citing Fortner Enterprises, Inc. v. United States Steel Corp., 394 U.S. 495, 498 (1969).); Town Sound and Custom Tops, 959 F.2d at 477 (holding that if the plaintiff satisfies the three-part per se tying test, "then the defendant's tying practices are automatically illegal without further proof of anticompetitive effect"); Digidyne Corp. v. Data General Corp., 734 F.2d 1336 (9th Cir. 1984) (If the court applies the per se approach then the "tying arrangement is illegal" without a showing that it "restrain[s] competition unreasonably.") (citations omitted).
} 
unreasonably restrained trade. This ill-conceived and outmoded categorization creates the worst of the both worlds - the cost of the rule of reason without its precision. ${ }^{200}$ The modified per se rule also creates a disconnect between section 1 and section 2 tying claims, since under section 2 more will be required.

To be sure, there might be an argument for a "middle" category if we thought that tying arrangements were anticompetitive if but only if the defendant had market power. But we're not persuaded that this two-sided correspondence between market power and anticompetitive effect is in fact true. ${ }^{201}$ The effect of this mischaracterization is that many courts do not sufficiently consider the likely (or actual) competitive effects of a challenged tie. Instead, they condemn tying arrangements that are likely to have no anticompetitive effects, simply because the particular tie-in satisfies the elements of tying's so-called per se test. In our view, tying belongs in the rule of reason box. But even if it doesn't - if there is a strong correspondence between market power and anticompetitive effect - courts should be up front about the creation of this intermediate category, rather than diluting the per se rule by calling things per se illegal that really aren't.

\footnotetext{
${ }^{200}$ See Jefferson Parish Hosp. Dist. No. 2 v. Hyde, 466 U.S. 2, 34-35 (1984) (O’Connor, J., concurring in the judgment) ("As a result, tying doctrine incurs the costs of a rule of reason approach without achieving its benefits: the doctrine calls for the extensive and time-consuming economic analysis characteristic of the rule of reason, but then may be interpreted to prohibit arrangements that economic analysis would show to be beneficial. Moreover, the per se label in the tying context has generated more confusion than coherent law because it appears to invite lower courts to omit the analysis of economic circumstances of the tie that has always been a necessary element of tying analysis.").

201 For an argument justifying a version of that distinction on the basis that tying conspiracies are more harmful than unilateral tying, see Christopher R. Leslie, Tying Conspiracies, $48 \mathbf{W m} . \boldsymbol{\&}$ Mary L. Rev. 2247 (2007). But cf. Jean Tirole, The Analysis of Tying Cases: A Primer, 1 Comp. Pol'y Int'l 1 (2005) (arguing for a unified treatment of all tying cases). But Leslie's argument deals only with horizontal conspiracies among competitors to impose ties on their customers. It does not extend to the full scope of the current "per se" rule in section 1 tying cases.
} 
Tying is an example of a category that lies, because it claims to be a per se rule but in fact involves many of the indicia of a rule of reason inquiry. Interestingly, Michael Carrier has suggested that rule of reason analysis itself may be an example in the opposite direction. Under the rule of reason, courts are supposed to balance the procompetitive benefits of conduct against its potential for anticompetitive harm. Carrier studies cases actually decided under section one and concluded that they tend to substitute burden-shifting presumptions for real balancing analysis. ${ }^{202} \mathrm{He}$ finds that courts dismiss most cases on the grounds that the plaintiff failed to show a significant anticompetitive effect. To some extent, Carrier's analysis may simply reflect evidence produced in the balancing inquiry, rather than a rejection of that inquiry. For example, if the plaintiff cannot prove market power in a section one case, it arguably makes sense not to proceed further under the rule of reason, since section one usually presumes harm only if a plaintiff has market power. ${ }^{203}$ But if Carrier is correct that more is going on here, rule of reason analysis may itself be a category that lies.

\section{Categories That Are Nonsensical}

Most of the categories we discuss in this paper, however problematic, are designed to get at distinctions that have some logical basis. Occasionally, however, antitrust courts adopt categories that simply make no sense. An example is the longstanding rule set out in General Electric v. United States that distinguishes between sales

\footnotetext{
${ }^{202}$ Michael A. Carrier, The Real Rule of Reason: Bridging the Disconnect, 1999 B.Y.U. L. Rev. 1265. Cf. Elhauge, supra note _ at 253 (challenging the way that cost-benefit analysis is applied in monopolization cases).

${ }^{203}$ But see Dennis Carlton, Market Definition: Use and Abuse, 3 Comp. Pol'y Int'1 1 (2007) (arguing that market power is an elusive concept that should not play a major role in antitrust analysis).
} 
and "licenses" of patented products. ${ }^{204}$ Antitrust law traditionally made resale price maintenance - the control over the price at which a buyer of a product can resell it illegal per se. ${ }^{205}$ But in General Electric, the Court said that that rule would be reversed if the supplier did not actually sell the product, but merely "licensed" it to the buyer. In that circumstance, even if the supplier physically transfers the goods to the buyer, the Court said price controls imposed by the supplier on the buyer were legal per se. ${ }^{206}$

There are a number of problems with the General Electric approach, not least the fact that the supplier and buyer in that case were actually competitors, and so allowing price control directly facilitated a cartel. ${ }^{207}$ Courts have criticized and limited General Electric,${ }^{208}$ and four Justices voted to overrule it in the 1940 s, ${ }^{209}$ but it remains the law. In this article, however, our concern is not so much with the unfortunate substantive dimensions of the General Electric rule as with the illogic of the categorical distinction between sales and licenses. Our experience with a similar distinction in software contracting is not promising: it has become an artificial distinction designed to reach particular legal results, not a distinction grounded in actual fact. ${ }^{210}$ The problem is even worse in antitrust law. It is trivial to manipulate the sale-license distinction, and the fact that the consequences of the distinction are so sharp - per se legality versus per se

204272 U.S. 476 (1926).

205 Dr. Miles Med. Co. v. John D. Park \& Sons, 220 U.S. 373 (1911). In 2007, the Supreme Court overruled Dr. Miles in Leegin Creative Leather Prods. v. PSKS, Inc., _ S.Ct.__ (June 28, 2007) (holding that resale price maintenance should be governed by the rule of reason).

206 General Electric, 272 U.S. at 490. Because General Electric created a rule of per se legality, the recent decision in Leegin to apply the rule of reason to other resale price maintenance schemes does not eliminate the effects of the sale-license distinction.

207 See 2 Hovenkamp et al., supra note _, at $\$ 31.1 \mathrm{~b}, 31.1 \mathrm{c}$.

208 See id. $\$ 31.2$.

209 Line Material Co. v. United States, 333 U.S. 287 (1948).

210 For discussions of the artificiality of this distinction, see, e.g., Mark A. Lemley et al., Software and Internet Law 317-24 (3d ed. 2006); David Nimmer, The Metamorphosis of Contract Into Expand, 87 Cal. L. Rev. 17 (1999); Jessica Litman, The Tales That Article $2 B$ Tells, 13 Berkeley Tech. L.J. 931 (1998). 
illegality - provide ample reason to do so. ${ }^{211}$ Worse, there is no real consequence

underlying the distinction. Transactions are not systematically less likely to be anticompetitive if structured as licenses rather than sales. We have created a rule that not only encourages manipulation and can facilitate cartels, but which has no affirmative value. $^{212}$

\section{E. Different Category Labels For the Same Conduct}

In the examples we have discussed so far, the courts have established rules that put cases into different boxes based on factual differences. We have argued that those factual differences are often not as important as the courts seem to think, that they are subject to manipulation, and that they can end up changing over time in surprising ways. In some cases, though, the problem is even worse. In the examples we consider in this section, the very same conduct will be treated differently by the courts depending on whether the courts give them one label or another.

\section{Predatory Bundling}

One important set of cases involves the bundling of different products. Bundling of two different products has traditionally been treated under the law of tying arrangements. As noted above, ties are illegal if they are coerced, the defendant has

\footnotetext{
211 Even after Leegin, which changed the rule against resale price maintenance from a per se rule to a rule of reason, there is still substantial value to an antitrust defendant of fitting into the per se legality box of General Electric.

212 In one context, the Robinson-Patman Act, the statute appears to require this distinction, because it applies only to sales. See Laitram Machinery, Inc. v. Carnitech A/S, 884 F.Supp. 1074, 1079-80 (E.D. La. 1995). We think that's a silly distinction too, but since it is one created by Congress, only Congress can undo it. General Electric was foisted on the world by the courts, and the courts can undo it.
} 
market power in the tying product, and there is an effect on the market for the tied product. While coercion normally involves a contractual requirement that the customer purchase product A if they want product B, courts have been willing to expand the concept of a tying arrangement to cases in which there is no express requirement but in which the financial incentives to purchase the products together are so strong that it is impractical to buy the goods separately. ${ }^{213}$

A more recent line of cases starting with LePage's $v .3 M^{214}$ treats the same sort of conduct under the label "predatory bundling." In LePage's, the defendant, 3M, made hundreds of diverse products. In some markets, it possessed considerable market power, while in others it faced significant competition. 3M had dominated the market for transparent tape, but was facing serious competition from LePage's. In response, 3M devised a "bundled rebate" program whereby retailers would receive ever increasing rebates as they met targets by purchasing products across $3 \mathrm{M}$ 's various product lines. As a result, even if retailers saved money by purchasing their tape from LePage's, they would lose significantly more in rebates across non-tape products that $3 \mathrm{M}$ had bundled with the tape.

The case illustrates how antitrust labels can be manipulated. The Third Circuit en banc affirmed the jury verdict against $3 \mathrm{M}$, holding that predatory bundling can violate section two. 3M attempted to characterize LePage's claim as one of predatory pricing.

213 See, e.g., United States v. Loew's, Inc., 371 U.S. 38, 50 (1962). Similarly, the first United States v. Microsoft case involved charges that Microsoft had imposed a de facto exclusive dealing arrangement by imposing a "per processor" license, under which computer makers could install whatever operating system they liked, but were obligated to pay Microsoft for each computer they shipped whether or not it contained the Microsoft OS. 1995 WL 505998 (D.D.C. 1995). The Antitrust Division alleged that the effect of this agreement was to force computer makers to load only Microsoft software, since to load other software they would have had to pay twice.

214324 F.3d 141 (3d Cir. 2003) (en banc). 
This is hardly surprising given that the Supreme Court has made predatory pricing a disfavored claim, which rarely succeeds. Alternatively, 3M's bundled rebate scheme could also be characterized as a tying arrangement since retailers who desired non-tape products from $3 \mathrm{M}$ were economically compelled to purchase tape as well given the rebate structure. Importantly, the legal standards the court applies to predatory bundling are different than the standards courts use in tying cases or in predatory pricing cases, even though the very same conduct will be at issue in many (though not all) cases. ${ }^{215}$ In at least some cases, therefore, whether the conduct is legal or not will depend on whether the conduct is put into the tying box (per se illegal, at least after market power is shown), the predatory pricing box (per se legal unless the price charged is below marginal cost), or the predatory bundling box (in which case the rule of reason is applied). ${ }^{216}$

\section{Refusals to License IP Rights}

A second example involves the treatment of potential liability for intellectual property owners who unilaterally refuse to license their IP rights to others. In a series of cases in the late 1990s, the courts of appeals created a varied set of rules for such "unilateral refusals to license." These rules vary, from an intent-based focus in the Ninth

215 See also Joshua D. Wright, Antitrust Law and Competition for Distribution, 23 Yale J. Reg. 169 (2006) ("Antitrust law has designed rules for each of these practices independently, ignoring the economic relationships between these business practices.").

216 The Ninth Circuit has sought to explain the relationship between bundling and predatory pricing, holding that bundling is not exclusionary unless it results in below-cost prices. See Cascade Health Solutions v. PeaceHealth, LLC, _ F.3d _ (9th Cir. 2007).

For an argument that product bundling under LePage's must be tested under predatory pricing standards, see Herbert Hovenkamp, Discounts and Exclusion, 2006 Utah L. Rev. 841; Daniel A. Crane, Mixed Bundling, Profit Sacrifice, and Consumer Welfare, 55 Emory L.J. 425 (2006). For an argument that it should be treated under the rule of reason, with a quick look initially applied, see Jonathan M. Lave, The Law and Economics of De Facto Exclusive Dealing, 50 Antitrust Bull. 143, 147 (2005). For an argument for a safe harbor based on market share, see Wright, supra note , at 169 . 
Circuit to a virtual rule of per se legality for unilateral refusals to license in the Federal Circuit. ${ }^{217}$ But in the dispute over the right standard for unilateral refusals to license IP, these courts have ignored a different legal doctrine that covers precisely the same conduct - the essential facilities doctrine. That doctrine also governs unilateral refusals to allow a plaintiff access to a facility, but it has an entirely different set of legal standards. Courts have generally applied the unilateral refusal to license caselaw to IP and the essential facilities caselaw to physical standards, but that correspondence is not absolute. ${ }^{218}$ More to the point, there is no reason that IP should be subject to a different set of rules than physical products. There may be reasons the two should lead to different results, for example because of the need to encourage innovation inherent in the IP system, but there is no reason to apply completely different legal rules. Once again, the outcome of a case may depend on nothing more than the choice of which legal rule to apply to the same set of facts.

\section{Tying}

A final example again involves categorizing conduct as involving tying. Tying arrangements require, among other things, proof that the defendant sold two distinct products and conditioned the sale of one on the purchase of the other. And because, as we have seen, tying is treated more harshly than unilateral conduct, antitrust plaintiffs have an incentive to characterize conduct as involving as tie of two different products rather than as monopolization. The need for characterization makes sense if the purpose

217 In re Independent Serv. Orgs. Antitrust Litig., 203 F.3d 1322 (Fed. Cir. 2000); Data General v. Grumman Sys. Support, 36 F.3d 1147 ( $1^{\text {st }}$ Cir. 1994); Image Tech. Servs. v. Eastman Kodak, 125 F.3d 1195 ( $9^{\text {th }}$ Cir. 1997).

218 For a discussion of occasional IP cases litigated under the essential facilities doctrine, see 1 Hovenkamp et al., supra note _, at $\S 13.3 \mathrm{c} 2$. 
of the anti-tying rule is to prevent firms with market power in one market from leveraging it into a separate market. But if the purpose is to prevent one firm from hurting equally or more efficient competitors, the separate products inquiry seems less necessary.

The separate products inquiry is subject to manipulation. Is it one product or two if the monopolist moves to tie before the market has evolved to allow sufficient independent demand for the tied product? What if there is a demand for the separate product, but there is also a strong demand for the two together, as with car stereos or tires? United States v. Microsoft is an obvious example. ${ }^{219}$ The parties fought for years over whether Internet Explorer was a separate product from Windows. Interestingly, the court created a whole new tying rule of reason specific to technological bundles, reversing the district court's finding of liability, and then found exactly the same conduct to constitute section 2 monopolization. The fact that the same conduct gets treated in different ways under different legal doctrines demonstrates the needless formalism inherent in the categorization approach.

\section{A More Nuanced Approach to Antitrust Analysis}

The reader may be forgiven for concluding at this point that we would abolish all categories in antitrust law. Not so. Categorization can serve an important role in antitrust analysis. We think, however, that courts must do a better job of considering each form of categorization and explicitly determining whether the benefits of categorical analysis in that case outweigh the downsides. In Part II, we itemized the many problems of current categorical analysis. Part III.A and B balance these problems by evaluating the benefits

219253 F.3d 34 (D.C. Cir. 2001) (en banc). 
of categorical analysis and weighing them against the general costs of categorization.

The remainder of Part III will discuss how courts can secure these benefits of categorical analysis while avoiding the problems we discussed in Part II.

Our discussion fits within a broader framework of legal scholarship on the choice between rules and standards. As that literature suggests, the tradeoff is generally one between certainty and accuracy. ${ }^{220}$ If neither costs nor uncertainty were a problem, standards would always be preferable to rules in antitrust cases because they are more likely to achieve the right result. That is, everything would be subject to an overarching rule of reason.

An antitrust jurisprudence based on standards is indeed more likely to reach the right result. But it is also likely to be more costly than a system of simple rules. The time and cost of full-scale antitrust litigation for every non-frivolous lawsuit would impose unacceptable costs of litigants and the court system overall as judicial resources were devoted to high-demand antitrust cases. The problem is worse than that, however. If parties could not reasonably and accurately predict the outcome of an antitrust case, they would find it very difficult to make reasonable business decisions. The result might be overdeterrence - businesses who avoided legitimate conduct because of the fear that it

220 The body of literature on this topic is extensive. See, e.g., Louis Kaplow, Rules versus Standards: An Economic Analysis, 42 Duke L.J. 557 (1992); Duncan Kennedy, Form and Substance in Private Law Adjudication, 89 Harv. L. Rev. 1685 (1976); Russell B. Korobkin, Behavioral Analysis and Legal Form: Rules vs. Standards Revisited, 79 Or. L. Rev. 23 (2000); Eric A. Posner, Standards, Rules, and Social Norms, 21 Harv. J.L. \& Pub. Pol'y 101 (1997); Frederick Schauer, Playing by the Rules: A Philosophical Examination of Rule-Based Decision-Making in Law and in Life (1991); Pierre Schlag, Rules and Standards, 33 UCLA L. Rev. 379 (1985); Cass R. Sunstein, Problems With Rules, 83 Cal. L. Rev. 953 (1995). 
would later be determined to be illegal. ${ }^{221}$ Or it might be underdeterrence, since plaintiffs as well as defendants bear court costs. ${ }^{222}$

Some rules, then, are necessary as a practical matter. The question is how we select the circumstances in which rules are appropriate. Sometimes rules make sense because we have enough experience with a particular practice that what we could learn from reconsidering a particular set of facts is not worth the costs of reopening the debate. There is no need to repeatedly debate the issue of whether horizontal price-fixing is necessarily a bad thing, for example. Antitrust defendants have already tried and failed many times to come up with good reasons to permit cartels; we gain very little by letting one more defendant have a go at it. In other cases rules are necessary because even if the court would benefit from a case-specific evaluation, the difficulty or uncertainty of the evaluation is too great. Antitrust has, for instance, a rule that courts will not consider the reasonableness of the fixed price. ${ }^{223}$ In theory, a standard for what constitutes a reasonable price is conceptually possible, but it would be difficult to implement because in reality it would be too hard to determine what a "reasonable price" would be.

But the administrative efficiency of rules should not always compel us to forego the accuracy of standards. The fact that there are classes of behavior that we know enough to characterize does not mean that categories are always or even usually the best approach. And as we have seen, many of the categories created in antitrust cases either make little economic sense or can be gamed so effectively that they do more harm than

221 Frank Easterbrook, The Limits of Antitrust, 63 Tex. L. Rev. 1 (1984).

222 Easterbrook didn't spend much time in his 1984 article worrying about this problem, but as antitrust has become far more defendant-friendly in the intervening two decades, it seems a more and more salient concern.

${ }^{223}$ U.S. v. Trenton Potteries Co., 273 U.S. 392 (1927). 
good. Antitrust is out of balance, leaning too heavily in favor of rules rather than

standards. In the sections that follow, we explore these issues in more detail.

\section{A. The Value of Categories}

There are several advantages to using categories when analyzing the reasonableness of trade restraints. First, the proper use of categories facilitates the efficient use of judicial resources. The primary advantage of the per se rule is that it "avoids the necessity for an incredibly complicated and prolonged economic investigation into the entire history of the industry involved, as well as related industries, in an effort to determine at large whether a particular restraint has been unreasonable-an inquiry so often wholly fruitless when undertaken." ${ }^{, 224}$ Full-blown rule of reason analysis draws on judicial and party resources much more than the per se approach. ${ }^{225}$ When properly applied, the per se rule allows courts to correctly and efficiently condemn manifestly unreasonable agreements. ${ }^{226}$ For example, bid-rigging is per se illegal, as it should be. Decades of empirical evidence have shown that bid-rigging schemes increase the price paid (often for government contracts) without any countervailing procompetitive justification. $^{227}$ While defendants in bid-rigging cases must be allowed to

${ }^{224}$ Northern Pac. Ry. Co. v. United States, 356 US. 1,5 (1958).

${ }^{225}$ See HERB HOVENKAMP, THE ANTITRUST ENTERPRISE 105 (2005) (litigating a rule of reason case is "one of the most costly procedures in antitrust practice"); Robert H. Lande, Are Antitrust "Treble” Damages Really Single Damages? 54 OHIO ST. L.J. 115, 147 n.153 (1993) ("For example, vertical nonprice cases today probably use more judicial resources on the average than they did 20 years ago.").

226 Jefferson Parish Hosp. Dist. No. 2 v. Hyde, 466 U.S. 2, 15 n.25 (1984) (“The rationale for per se rules in part is to avoid a burdensome inquiry into actual market conditions in situations where the likelihood of anticompetitive conduct is so great as to render unjustified the costs of determining whether the particular case at bar involves anticompetitive conduct.") (citing Arizona v. Maricopa County Medical Society, 457 U.S. 332, 350-351 (1982)).

${ }^{227}$ See, e.g., Charles A. BANE, The EleCtrical EQuipMent ConspiraCies (1973); John G. Fuller,

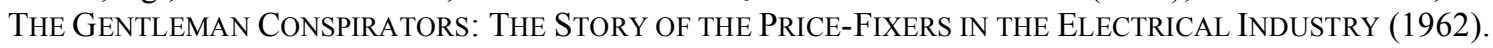


contend that they did not in fact rig any bids, it would unnecessarily waste judicial resources to permit them to dispute argue to a jury that their rigged bids were reasonable or otherwise justifiable. The per se approach preserves judicial time and resources to better consider those restraints whose competitive effects are less clear. ${ }^{228}$

Second, categories can provide the basis for bright-line legal rules, which facilitate business planning by clearly articulating what types of agreements are permissible. Properly implemented, per se rules are bright-line rules that provide certainty. $^{229}$ While firms may not necessarily favor certain agreements being categorically condemned, "per se rules tend to provide guidance to the business community." ${ }^{, 230}$ Businesses know not to fix prices or allocate territory with their competitors, or to rig bids. With these profit-maximizing methods off the table, firms can concentrate on legal ways to increase their bottom line.

In addition to categories of restraints that are per se illegal, some conduct is per se legal. Courts have, for instance, created safe harbors that protect unilateral termination of dealers $^{231}$ and allow a monopolist to drive competitors from the market by charging a low but above-cost price. Designed properly, these bright-line rules are perhaps even more

\footnotetext{
${ }^{228}$ ABA Antitrust Section, Monograph no. 23, The Rule of Reason, 3 (1999) ("Application of the per se approach frees the court from an inquiry into whether the arrangement at issue has actually harmed consumers or thwarted free market competitive forces."); ABA RULE OF REASON MONOGRAPH, supra note $\mathrm{xx}$ at 3 ("Indirect cost savings also are achieved by allowing regulators and the judiciary to focus resources on cases that are not clearly anticompetitive and may present real procompetitive efficiencies.").

${ }^{229}$ Northern Pac. Ry. Co. v. United States, 356 US. 1,5 (1958) (The "principle of per se unreasonableness ... makes the type of restraints which are proscribed by the Sherman Act more certain to the benefit of everyone concerned.").

${ }^{230}$ GTE Sylvania Inc., 433 U.S. 36, 50 n. 16 (1977).

231 Monsanto Corp. v. Spray-Rite Corp., 465 U.S. 752 (1984).
} 
valuable because they allow firms to pursue a business strategy openly and aggressively without fear of legal liability. In sum, categories can enhance predictability. ${ }^{232}$

Third, in some cases, categories can provide a red flag for judges about whether a challenged restraint is likely to have anticompetitive consequences. For example, horizontal restraints are more likely to cause anticompetitive concerns than vertical restraints. Knowing this helps alert the court to the possibility (or probability) of anticompetitive effects when an agreement is clearly both horizontal and price-related. Conversely, the court may be less suspicious of a restraint when it is clearly vertical and not related to price. There is nothing wrong with judges using these broad truths as a filter. But this filter only makes sense when the categorization is unambiguous and uncontroverted. The problem lies in courts investing an inordinate amount of time on determining the proper category when the purpose of the categorization is to simplify the inquiry.

\section{B. Currently, the Costs of Categories Outweigh Their Benefits.}

The benefits of categorical analysis need to be balanced against the costs. ${ }^{233}$ Despite the potential benefits of categorical analysis, the process of categorization in antitrust has unnecessarily imposed significant costs. Further, the manner in which courts have pursued categorical analysis has often undermined the very benefits that a categorical approach is intended to achieve.

\footnotetext{
${ }^{232}$ See Cavanagh, supra note $\mathrm{xx}$ at 1335 ("[Per se] rules are justified when their benefits, such as administrative efficiency, ease of application, and predictability, outweigh any negative effects on antitrust enforcement.").

233 See, e.g., Mark S. Popofsky, Defining Exclusionary Conduct: Section 2, the Rule of Reason, and the Unifying Principle Underlying Antitrust Rules, 73 Antitrust L.J. 435, 458 (2006)

(discussing the tradeoffs between rules and standards in antitrust).
} 
First, the current reliance on categories - especially when coupled with the per se rule - risks false positives (i.e., findings of liability when the correct result should be no antitrust liability). When courts focus on categorization instead of competitive effects, it increases the probability of mistakes. The Court has acknowledged that in applying the per se rule "[f]or the sake of business certainty and litigation efficiency, we have tolerated the invalidation of some agreements that a full-blown inquiry might have proved to be reasonable." ${ }^{234}$ But the Court has justified the risk of false positives by reasoning that if the categories are drawn appropriately, then instances of false positives "are not sufficiently common or important to justify the time and expense necessary to identify them." 235 Unfortunately, like most bright-line rules, "[p]er se rules always contain a degree of arbitrariness" 236 and it remains unclear how many false positives are created by the current categorical approach. Certainly in the decade between Schwinn and Sylvania, there must have been false positives when non-price vertical restraints were condemned as per se illegal.

In many instances, it is the obsession with categories that can itself create the false positive. For example, the facile categorization of the agreement in Topco as horizontal blinded the Court to the actual competitive effects of agreement among small and mid-size grocers to create a new brand of products to compete against larger chain

\footnotetext{
${ }^{234}$ Arizona v/ Maricopa county Med. Soc'y, 457 U.S. 332, 344 (1982); ABA RULE OF REASON MONOGRAPH, supra note $\mathrm{xx}$ at 3-4 ("[o]ccasionally, per se treatment may condemn a practice that under a specific set of circumstances might have survived rule of reason analysis; these 'errors' are tolerated for the sake of business certainty and litigation efficiency.") (citing Arizona v/ Maricopa county Med. Soc'y, 457 U.S. 332, 343 (1982)).

${ }^{235}$ GTE Sylvania Inc., 433 U.S. 36, 50 n. 16 (1977).

${ }^{236}$ United States v. Container Corp., 393 U.S. 333, 341 (1969) (Marshall J., dissenting); see also Edward D. Cavanagh, Contribution, Claim Reduction, and Individual Treble Damage Responsibility: Which Path to Reform of Antitrust Remedies?, 40 VAND. L. REV. 1277, 1335 (1987) ("Bright-line rules always contain some degree of arbitrariness.").
} 
stores. As a result, the Court is widely considered to have reached the wrong result in Tорсо. ${ }^{237}$ In short, in some cases antitrust condemns anticompetitive agreements that have the potential for increasing consumer welfare or are otherwise efficient. ${ }^{238}$

In addition to false positives, the current categorical approach probably results in false negatives as well. The conventional wisdom is that vertical restraints evaluated under the rule of reason are essentially de facto per se legal since rule of reason cases are notoriously difficult for plaintiffs to win. ${ }^{239}$ As Justice Breyer pointed out in his dissent questioning use of the rule of reason in Leegin, "One cannot fairly expect judges and juries in such cases to apply complex economic criteria without making a considerable number of mistakes, which themselves may impose serious costs." ${ }^{240}$ False negatives are bad because anticompetitive conduct - which reduces consumer welfare - goes undeterred. The specific conduct at issue in a particular case can continue unfettered and other firms are encouraged to undertake similar inefficient conduct. ${ }^{241}$

\footnotetext{
${ }^{237}$ HOVENKAMP (“ANTITRUST ENTERPRISE”), supra note _ at 122 (“If stare decisis had been applied to a methodology of antitrust analysis, rather than simply to the category of "market division," the outcome would have been different.").

${ }^{238}$ For example, horizontal price that reduces output in markets characterized by negative externalities can increase efficiency. See Christopher R. Leslie, Achieving Efficiency Through Collusion: A Market Failure Defense to Horizontal Price-Fixing, 81 CALIFORNIA LAW REVIEW 243 (1993).

${ }^{239}$ But see Outboard Marine Corp. v. Pezetel, 461 F.Supp. 384, (D. Del. 1978) (In "establishing instead a rule of reason with respect to vertical restraints, Sylvania does not stand for the proposition that such restraints are per se legal.")

240 (page 10 of Breyer's dissent).

241 Dan Crane argues that the prospect of treble damages for antitrust violations means that antitrust is "powerfully structured to deter violations." Crane, supra note _, at 89. For a contrary view, explaining why standing doctrines and other antitrust limits mean that treble damages often under-deter, see Robert H. Lande, Why Antitrust Damage Levels Should Be Raised, 16 Loyola Cons. L. Rev. 329 (2004); Robert H. Lande, Five Myths About Antitrust Damages, 40 U.S.F. L. Rev. 651 (2006). In our view, Lande has the better of this argument. While the prospect of treble damages can deter conduct, and therefore avoid false negatives, the deterrence calculus must take into account the difficulties of proving an antitrust case, and the low likelihood of success facing antitrust plaintiffs. To take just one example, Hammer and Sage's comprehensive study of health care antitrust litigation found that plaintiffs win only $14 \%$
} 
More generally, categorical approaches produce inaccurate outcomes.

Unfortunately, plaintiffs have a powerful incentive to create false positives, and defendants have a corresponding incentive to create false negatives. Of course, plaintiffs want to create true positives and defendants true negatives as well. Often, both sides in litigation sincerely believe that their position is correct. But litigants are generally more concerned with winning than the court reaching the "right" result. Given these incentives, categorical analysis can distract the court from focusing on the actual or likely economic effects of the challenged restraint, as both plaintiffs and defendants may argue that effects are irrelevant - plaintiffs because the restraint is horizontal and therefore unreasonable as a matter of law, and defendants because their conduct was vertical and thus necessarily harmless. And the fact that many cases don't fit easily within a particular box, or that some different categories cover the same conduct, gives lawyers ample opportunity to game this system. The prospect of strategic behavior by both antitrust plaintiffs and defendants to fit their case within a favorable box further distorts outcomes away from efficiency. ${ }^{242}$

Second, courts often spend more time on the categorization process than they would on the process of performing proper analysis of the competitive effects of a challenged restraint. This negates the supposed efficiency advantages of categorization.

of the antitrust cases in the health care industry. Peter J. Hammer \& William M. Sage, Antitrust, Health Care Quality, and the Courts, 102 Colum. L. Rev. 545, 575 (2002). While health care cases may be unrepresentative, it is certainly not the case that plaintiffs in any field are winning antitrust cases in droves in the modern era.

242 For this reason, we think Crane has it backwards when he suggests that standards rather than rules are more likely to lead to strategic behavior and public choice concerns. Crane, supra note _, at 97-98. Long experience has shown that it is narrow rules and Congress and administrative agencies that are more subject to public choice worries than the judiciary. A standard based on efficiency is particularly hard to manipulate by strategic behavior. As we note below, however, we do agree with Crane about the importance of some screens to weed out frivolous claims and defenses without putting the parties to great expense. 
For example, courts invest their energies asking, "Does the conduct fall in the category 'group boycott' or not? If so, does it fall in the per se category?" As courts focus on the horizontal-vertical debate, they miss sight of the true purpose of antitrust law: condemning restraints that unreasonably reduce consumer welfare. Professor Baker has astutely observed that "the business certainty and litigation cost reduction benefits of per se rules are easy to overstate. The fight over characterization -- determining which pigeonhole -- can involve as much cost, can generate as little business certainty, as a fullblown analysis of reasonableness." ${ }^{243}$ Far from generating efficiencies and saving judicial resources, courts can expend more time attempting to characterize a restraint than it would take to actually analyze the competitive effects of the challenged agreement. ${ }^{244}$ And at the end of the day, the information this fight will have produced is far less useful than would be the results of a direct inquiry into competitive effects.

Third, while categorical reasoning and per se rules are supposed to increase predictability and consistency, these benefits of categorical analysis have gone largely unrealized. Shifting categories that leave ill-defined categories in their wakes reduce the predictability and clarity of antitrust doctrine. While the Court may find the virtue of flexibility in its admission that there is often no "bright line separating per se from rule of reason analysis, ${ }^{, 245}$ in the context of a categorical legal framework, the result is mass confusion. While some restraints are condemned without any analysis of their probable

${ }^{243}$ Jonathan Baker, Per Se Rules in the Antitrust Analysis of Horizontal Restraints, 36 ANTITRUST BULL. 733, 740 n.29 (1991)).

${ }^{244}$ HOVENKAMP (“ANTITRUST ENTERPRISE"), supra note _ at 115 ("So conduct must be characterized before it can be made subject to the per se rule. Furthermore, the characterization process must be less costly than a full rule of reason analysis. Otherwise the per se rule would be pointless. If determining that something ought to be governed by the per se rule is just as costly as applying the rule of reason, then we haven't saved anything.").

${ }^{245}$ Nat'l Collegiate Athletic Ass'n v. Bd. of Regents of Univ. of Okla., 468 U.S. 85, 104 n.26 (1984) 
effects, in "other cases, [courts] have ignored seemingly intractable antitrust principles in refusing to apply the per se rule to restraints that likely would have been categorized as per se offenses in the not-so-distant past. As a result, we are left with no clearly discernible rule to govern application of the per se rule. ${ }^{, 246}$ On a practical level, this lack of clarity can make it harder for antitrust plaintiffs to get a good attorney, as lawyers are reluctant to invest the necessary resources in a case whose course and outcome is so uncertain. $^{247}$

Finally, error costs - false positives and false negatives - must be balanced against administrative benefits. Bright-line rules may be acceptable, despite their error costs, because they conserve judicial resources. However, the error costs associated with the categorical approach in antitrust are not offset by administrative savings because, as we have shown, categorical analysis often requires more effort than an inquiry into the actual competitive effects of a challenged restraint. In short, the categorical approach entails both error costs and administrative costs - the worst of both worlds.

All of this suggests that the approach to categorization is not cost-beneficial. Categorization serves an important role when it simplifies the analysis. However, when courts spend as much time trying to categorize the conduct as they would determining its actual competitive consequences, then categorization is a net negative - it produces

\footnotetext{
${ }^{246}$ ABA RULE OF REASON MONOGRAPH, supra note $\mathrm{xx}$ at 12.

247 ABA Antitrust Section, Monograph No. 13, Treble Damages Remedy (1986) ("The necessary economic incentive for a plaintiff and its attorney may not be supplied by a system that only compensates the plaintiff for its actual damages if it wins, because such a system may not provide sufficient return to overcome the risks of litigation."' Particularly for complex, uncertain litigation-such as rule of-reason cases-a multiplier may be necessary to induce the necessary expenditures to develop evidence sufficient to meet the plaintiff's burden of proof.").
} 
inaccurate outcomes without the cost savings or predictability promised by bright-line rules. Currently, lawyers and judges spend an inordinate amount of time attempting to characterize a restraint along a variety of dimensions. For example, in the cases discussed in Part Two, courts focused a lot of time on determining whether the restraint is more appropriately categorized as horizontal or vertical. This misses the forest for the trees. Categorization takes the courts' time and attention but does not necessarily achieve better results than a rule of reason analysis. Except in a few special cases, courts should focus on competitive effects, not on how the restraint is characterized.

\section{On the Correct Use of Categories in Antitrust}

While the purpose of this Article is to expose the overreliance on and misuse of categorical analysis in antitrust jurisprudence, it would be improper to criticize the current use of categories in antitrust without offering suggestions for courts on how to consider categories when evaluating antitrust claims. However, the goal of this section is not to advance a new overarching basis for antitrust jurisprudence - that is a separate article, more ambitious than this effort. Rather, our goal is more modest - to provide an overview of how courts should approach antitrust issues without over-relying on categories.

Any use of categorical analysis in antitrust decision-making should be performed with an eye toward the goals of antitrust law: to detect and deter trade restraints that unreasonably reduce output, raise price, or diminish competition with respect to quality, 
innovation, or consumer choice. When categorical reasoning does not help the decisionmaker identify and condemn unreasonable trade restraints, such an approach is at best unnecessary and at worst counterproductive, causing courts to reach incorrect results and creating confusion within the business community, including those who genuinely want to operate within the law.

To insure the proper use of categorical analysis, this section argues that courts should do three things: (1) forego categorizing restraints when the plaintiff proves anticompetitive effects through direct evidence; (2) properly define the contours of antitrust categories based on empirical evidence; and (3) constrain the use of categorical scrutiny when performing rule of reason analysis.

1. When Antitrust Analysis Should Eschew Categories

Categorical analysis is useful when it appropriately simplifies analysis that would otherwise be overly complex. But categorical analysis is not always necessary or appropriate. The process of characterizing a challenged restraint along the various vectors of horizontal versus vertical and price versus nonprice has become the default starting point in much antitrust analysis. While it may be second nature to categorize, judicial efficiency can be maximized if other things are considered first.

Categorical analysis is intended to help judges determined whether or not the challenge conduct is likely to cause anticompetitive effects. But there is no need to 
engage in categorical analysis when plaintiffs present direct evidence of anticompetitive effects. In addition, the court need not engage in the taxing and often expensive process of defining the relevant product and geographic market, determining whether or not the defendants have market power within that market. ${ }^{248}$

While some courts have indicated that a plaintiff can rely on evidence of direct economic effects in lieu of defining the relevant market and proving that the defendants have sufficient market power to unreasonably restrain trade, ${ }^{249}$ other courts have sought to limit the role of direct evidence of economic effect, while overemphasizing a categorical approach. ${ }^{250}$ The Seventh Circuit has held that direct evidence can substitute for economic theory only in horizontal, not vertical, restraints. ${ }^{251}$ This approach is flawed: direct evidence of anticompetitive effects should be sufficient to establish the plaintiff's prima facie case regardless of whether or the restraint is categorized as horizontal or vertical. The Seventh Circuit rule makes the antitrust analysis turn on irrelevant categorization. If the plaintiff has direct evidence of anticompetitive effects, then the parties will necessarily engage in a heated debate as to whether the restraint at issue is horizontal or vertical. The plaintiff must establish that the restraint is horizontal in order to ensure that its direct evidence will be sufficient to establish the prima facie case. And, conversely, the defendant will argue that the restraint is vertical and therefore the presence of direct evidence is not dispositive. This elevates form over substance as

\footnotetext{
${ }^{248}$ The defendant may still be able to argue an efficiency defense, but this currently takes place outside of categorical contours, as it should.

249 See, e.g., Indiana Federation of Dentists, 476 U.S. at 460 (circumstantial evidence of market power is but a "surrogate" for direct evidence of market effects); Toys'r'Us, Inc. v. FTC, $221 \mathrm{~F} .3 \mathrm{~d} 928$ ( th $^{\text {th }} \mathrm{Cir}$. 2000).

${ }^{250}$ See Republic Tobacco Co. v. North Atlantic Trading Co., 381 F.3d 717 (7th Cir. 2004). ${ }^{251} I d$.
} 
the parties debate how to categorize a restraint even when the court has direct evidence on the ultimate question that categorization is intended to help answer: Did the restraint cause anticompetitive effects? The categorization debate in such cases is at best a red herring that wastes judicial and party resources on an unnecessary and complicated inquiry; at worst, the risk of false negatives is magnified as courts ignore direct evidence in favor of irrelevant disputes about characterization.

We believe that the problems with categorization can be minimized if antitrust law pays more attention to direct evidence of anticompetitive effects, rather than focusing on putting conduct into a particular category, and then reasoning from the category into which it has been put whether or not there are in theory likely to be anticompetitive effects. $^{252}$ By championing categorical analysis, the Seventh Circuit approach too quickly discounts reliable evidence of actual economic effects. ${ }^{253}$ This is a mistake because, as we have seen, the categories that are the basis for this economic reasoning are uncertain, problematic, and subject to manipulation.

\section{Categorization Should Have an Empirical Basis}

Categories should reflect the wisdom of empirical evidence. This is particularly important when the categorical label is dispositive, as the per se rule is. The Supreme Court has asserted that "[i]t is only after considerable experience with certain business

${ }^{252}$ See Dennis Carlton, Market Definition: Use and Abuse, 3 COMP. POL'Y INT'L 1 (2007).

${ }^{253}$ While some may argue that such evidence might be manipulated, direct evidence is less malleable than current categorical labels. 
relationships that courts classify them as per se violations of the Sherman Act." 254 The per se rule attempts to convert judicial experience into a labor-saving device: after courts have seen a particular type of restraint and have condemned it repeatedly under a rule of reason analysis, that category of restraint warrants per se condemnation because courts can "predict with confidence that the rule of reason will condemn it." 255 In theory, this also means that the lack of judicial experience with a category of restraints means the court will apply the rule of reason. ${ }^{256}$

Despite such paeans to empiricism, federal courts do not always create categories based on empirical evidence and judicial experience. For example, federal courts have condemned tying arrangements as nominally per se illegal for decades without any empirical proof that tying always or almost always unreasonably restrain competition in the market for the tied product. Similarly, the Supreme Court in Maricopa County Medical Society condemned maximum price fixing agreements, the majority being "unpersuaded by the argument that we should not apply the per se rule in this case

\footnotetext{
${ }^{254}$ U.S. v. Topco Associates, Inc., 405 U.S. 596, 607-08 (1972) (citing Van Cise, The Future of Per Se in Antitrust Law, 50 VAND. L. REV. 1165 (1964)); see Broadcast Music, Inc. v. Columbia Broadcasting System, Inc., 441 U.S. 1, 10 (1979) (quoting Topco).

${ }^{255}$ Maricopa County Medical Society, 457 U.S. 332, 344 (1982); see State Oil Co. v. Khan, 522 U.S. 3, 10 (1997) (quoting Maricopa County); Atlantic Richfield Co. v. USA Petroleum Co., 495 U.S. 328, 342

(1990) (same); F.T.C. v. Superior Court Trial Lawyers Ass'n, 493 U.S. 411, 433 (1990) (same).

The abbreviated rule of reason is based on experience as well. See California Dental Ass'n v. F.T.C., 526 U.S. 756, 781 (1999) ("The object is to see whether the experience of the market has been so clear, or necessarily will be, that a confident conclusion about the principal tendency of a restriction will follow from a quick (or at least quicker) look, in place of a more sedulous one.").

${ }^{256}$ See, e.g., Broadcast Music, Inc. v. Columbia Broadcasting System, Inc., 441 U.S. 1, 10 (1979) ("experience hardly counsels that we should outlaw the blanket license as a per se restraint of trade."); Appalachian Coals v. U.S., 288 U.S. 344, 377 (1933) ("Nothing in theory or experience indicates that the selection of a common selling agency to represent a number of producers should be deemed to be more abnormal than the formation of a huge corporation bringing various independent units into one ownership."); $c f$. National Collegiate Athletic Ass'n v. Board of Regents of University of Oklahoma, 468 U.S. 85, 1001984) ("we have decided that it would be inappropriate to apply a per se rule to this case. This decision is not based on a lack of judicial experience with this type of arrangement...").
} 
because the judiciary has little antitrust experience in the health care industry."257 The Court had not developed empirical evidence about the anticompetitive effects of maximum price-fixing agreements in general. But that did not stop the court from putting such agreements in the per se category.

Applying an empirical test, at least some trade restraints clearly belong in the per se category, most notably bid-rigging, cartel agreements to fix a minimum price, and agreements to artificially reduce output. Federal courts have over a century's worth of empirical evidence that shows that cartels raise price, reducing consumer welfare and creating inefficiency. ${ }^{258}$ Similarly, bid-rigging schemes increase the cost of government contracts, draining the public coffers without any offsetting efficiency gains. These types of agreements are properly categorized as per se illegal because the empirical evidence comports with that legal conclusion.

Of course, an empirical approach can also support the creation of categories of conduct that are per se legal. Nonexclusive patent licenses, for instance, are restraints of trade, but long experience has taught that they are not unreasonable restraints of trade, and the grant of a patent license is not itself problematic. ${ }^{259}$ Similarly, a unilateral

\footnotetext{
257457 U.S. at 349.

258 One problem with the current approach to empiricism is the limited construction of what constitutes relevant empirical data. The Court has articulated a standard based on judicial experience. The concept of empiricism should be expanded to include economic case studies performed by qualified academics. Case studies can represent a fount of in-depth and dependable information. Incorporating non-judicial sources of reliable empirical data would save courts from having to engage in repeated costly rule of reason analyses before having sufficient data that a category of restraint warrants per se treatment.

259 U.S. Department of Justice and Federal Trade Commission, Antitrust Guidelines for the Licensing of Intellectual Property sec. 3.1 (1995).
} 
decision to set a nonpredatory price is legal per se, because antitrust law has concluded that even if artificially high prices reduce social welfare in some circumstances, the costs of judicial scrutiny of the myriad pricing decisions made by dominant firms would far exceed the benefits. Such conduct is per se legal because we have considerable empirical data that such agreements and pricing decisions do not reduce output or raise price; indeed, they tend to have the opposite effect. As with per se illegal conduct, challenged restraints shold not fall into the per se category until sufficient empirical evidence - in the form of reliable case studies and/or litigation - demonstrates that the type of restraint does not unreasonably restrain competition. Theory alone should not move agreements into the safe harbor of per se legality. Rather, agreements should be categorized according to their empirically demonstrated procompetitive or anticompetitive effects.

But whether developing rules for per se legality or illegality, antitrust courts should create categories only when the facts warrant it. If antitrust analysis leads to consistent results across a range of circumstances - if particular conduct is always harmful, never harmful, or harmful only in a defined class of cases - then the creation of an antitrust rule is appropriate. But one of the lessons of Part II is that even then courts are not done. Factual circumstances can change, and categorizing new conduct merely by analogizing it to previously categorized conduct is insufficient if the new conduct has different economic effects. Reasoning by analogy is not empirical analysis and is not helpful if the debate over how to analogize and categorize overshadows the more important inquiry into a restraint's effects on competitive conditions. 
Properly understood, therefore, even bright-line rules require detailed antitrust analysis into the economic effects of the conduct at issue. It is just that that analysis occurs in bulk rather than on a case-by-case basis. Further, courts need to be far more sensitive than they have been to the possibility of gaming the rules they create or making inefficient changes in behavior in order to fit within an established category.

3. The Clarity of Categories and Antitrust Analysis Beyond the Constraints of Categories

Most restraints will not fall in a per se category. Particular conduct will have different one potential anticompetitive effects based on many market characteristics: the number, market share, product diversification, and financial strength of competitors; the response of consumers, competitors, and venture capitalists to particular circumstances; and the structure, regulatory environment, time to market, and barriers to entry in the particular industry, to name but a few. All these characteristics vary from market to market. $^{260}$ Thus, context is important for determining whether or not a particular restraint is unreasonably anti-competitive. The Supreme Court essentially recognized this in Sylvania when it declared that "departure from the rule-of-reason standard must be based upon demonstrable economic effect rather than . . . upon formalistic line drawing."261

260 See Jonathan B. Baker \& Timothy F. Bresnahan, Economic Evidence in Antitrust: Defining Markets and Measuring Market Power, available at http://papers.ssrn.com/sol3/papers.cfm?abstract_id=931225 (working paper 2006) (arguing that antitrust should take into account the empirical economic learning on how market effects differ by industry).

261 Continental T.V. v. GTE Sylvania Inc., 433 U.S. 36, 58-59 (1977). 
If a challenged trade restraint does not appropriately belong in a per se category, then courts apply rule of reason analysis. Under the rule of reason, the fact finder must determine whether or not the challenge restraint unreasonably reduces output or injures price or nonprice competition. It is here -- during the rule of reason discussion -- that courts sometimes over-rely on categorical analysis as a dangerous crutch.

Proper application of the rule of reason need not - and generally should not involve categorical analysis. The most important components of a thorough rule of reason analysis do not require reliance on categories but on particular evidence about the nature and effects of a particular restraint in a particular market context. Assuming that the challenged restraint does not fall within a per se category - and is not so facially anticompetitive that it warrants condemnation under the quick look - the court should inquire into the defendants' market power. ${ }^{262}$ Firms without market power are unlikely to reduce output or increase price in a consequential way. Thus, in the absence of any meaningful market power the court can dispose of the case without additional categorical analysis being performed doing a rule of reason application.

If the defendants do collectively possess market power, then the court must determine whether the challenged agreement is likely to produce anticompetitive effects. Once the court reaches this step in the rule of reason, categories can provide insights but should not be dispositive. The empirical evidence suggests that a horizontal price restraint is more likely to have anticompetitive effects than a comparable vertical

\footnotetext{
${ }^{262}$ Of course, if the plaintiff can prove actual anticompetitive effects from the challenge restraint, then courts can condemn the restraint without elaborate inquiry into market definition and market power.
} 
nonprice restraint. But this insights applies to restraints that are clearly horizontal and price-related (such as, price-fixing among competitors) or clearly vertical and not pricerelated (such as a manufacturer's assignment of territorial responsibilities among its distributors). If a challenged restraint is not neatly fit with in a recognized category, then court should not invest significant time and effort trying to pigeonhole the restraint. Categorical analysis is only appropriate if it accurately and efficiently simplifies the adjudication process. However, as Part Two illustrated, the process of characterizing challenged restraint along a variety of categorical boxes often introduces more confusion than clarity.

The remainder of the rule of reason process need not involve any reference to antitrust categories. If the plaintiff can establish the defendants' market power and prove a prima facie case that the restraint is likely to have an anticompetitive effect, the defendant is given the opportunity to show that the restraint also creates meaningful efficiencies that could not be realized in the absence of the restraint - in other words, the efficiencies cannot be realized through a less restrictive alternative. Presented with the plaintiff's prima facie case of anticompetitive effects and the defendant's colorable claim of efficiencies, the court should engage in a balancing process to determine whether or not the likely anticompetitive effects outweigh the probable efficiencies from the restraint.

Our objective in this Article is not to describe a legal test for how courts should perform this balancing - or how to define markets, how to assess market power, or how 
to evaluate efficiency claims. Our goal is simply to convince federal judges not to overrely on the comfort of categories when performing rule of reason analysis. Judges should recognize that none of the steps in a proper rule of reason analysis - market definition, market power, anticompetitive effects, efficiency arguments, or balancing - requires the court to employ categorical reasoning.

The thrust of our argument is to explain why categorical analysis in antitrust jurisprudence is flawed. Our focus in this Article is more on diagnosis and less on treatment. Eminent scholars like Herb Hovenkamp have proposed frameworks for evaluating trade restraints under section one. Unfortunately, federal judges are unlikely to adopt new, more appropriate legal tests absent an appreciation of why their current approach is inefficient and misguided. This Article attempts to give impetus to alternative approaches by showing how categorical gives merely the illusion of precision at considerable (and unnecessary) expense, as measured in accuracy and judicial resources.

\section{Conclusion}

Like the early classifications performed during the Enlightenment, the process of classifying trade restraints proved to be a valuable tool in early deliberations about how to determine what conduct should be considered unreasonable and thus violative of antitrust laws. But, over time, as categories have shifted and become subject to manipulation, they no longer accurately describe competitive conditions. Blind reliance 
on the categories of yesteryear unnecessarily complicates antitrust litigation, creates inaccurate results, and creates perverse incentives for American businesses. Antitrust jurisprudence would benefit significantly from a re-examination of antitrust categories, including the abandonment of out-moded characterizations and assumptions, coupled with a greater reliance on empirical evidence to hone more apt rules and better applied standards.

Only if courts keep the goals of the antitrust inquiry firmly in mind can they avoid being distracted by the allure of ultimately empty boxes. It's not important whether the platypus is a reptile or a mammal; what's important is that it's a platypus. 